Article

\title{
Dissemination of Social Accounting Information: A Bibliometric Review
}

\author{
Margarida Rodrigues ${ }^{1}$, Maria do Céu Alves ${ }^{2} \mathbb{D}$, Cidália Oliveira ${ }^{3} \mathbb{D}$, Vera Vale ${ }^{4} \mathbb{D}$, José Vale ${ }^{5}$ and Rui Silva ${ }^{6, * \mathbb{D}}$ \\ 1 CEFAGE (Center for Advanced Studies in Management and Economics), University of Beira Interior, \\ 6201-001 Covilhã, Portugal; mmmrodrigues@sapo.pt \\ 2 NECE (Center for Studies in Business Sciences), University of Beira Interior, 6201-001 Covilhã, Portugal; \\ mceu@ubi.pt \\ 3 NIPE (Centre for Research in Economics and Management), University of Minho, 4704-553 Braga, Portugal; \\ cidalia.oliveira@eeg.uminho.pt \\ 4 Department of Economics, Management, Industrial Engineering and Tourism (DEGEIT), \\ GOVCOPP and CEOS.PP, University of Aveiro, 3810-193 Aveiro, Portugal; v.c.vale@ua.pt \\ 5 Porto Accounting and Business School and CEOS.PP, Polytechnic Institute of Porto, 4465-004 Porto, Portugal; \\ josevale@iscap.ipp.pt \\ 6 CETRAD (Centre for Transdisciplinary Development Studies), University of Trás-os-Montes e Alto Douro, \\ 5001-801 Vila Real, Portugal \\ * Correspondence: ruisilva@utad.pt
}

Citation: Rodrigues, Margarida, Maria do Céu Alves, Cidália Oliveira, Vera Vale, José Vale, and Rui Silva. 2021. Dissemination of Social Accounting Information: A Bibliometric Review. Economies 9: 41. https://doi.org/10.3390/economies 9010041

Received: 11 February 2021

Accepted: 11 March 2021

Published: 19 March 2021

Publisher's Note: MDPI stays neutral with regard to jurisdictional claims in published maps and institutional affiliations.

Copyright: (c) 2021 by the authors. Licensee MDPI, Basel, Switzerland. This article is an open access article distributed under the terms and conditions of the Creative Commons Attribution (CC BY) license (https:// creativecommons.org/licenses/by/ $4.0 /)$.

\begin{abstract}
The discussion in recent decades about sustainable development issues has given rise to a new accounting dimension: social accounting. Currently, this issue remains an emerging theme. Although there are some studies and literature reviews, none include disclosure of social accounting information or the analysis of research paradigms. This article reviews the research on social accounting disclosure and tries to answer the following research questions: What research streams have been followed? Which theories and research paradigms have been used? The search for articles to be included in the literature review was performed through the Web of Science. The 126 articles obtained were later analyzed using Bibliometrix software. Results expose the growing interest in this theme and identify three distinct research lines (three clusters): Cluster 1-Social accounting disclosures, Cluster 2-Legitimacy vs. disclosure of social accounting, and Cluster 3-Motivations for disclosure of social accounting. The main contribute of this article resides, on the one hand, in the fact that no literature review articles have been found that include the theme of the disclosure of information on social accounting and, on the other hand, the treatment of data has been done with innovative software, an R package for bibliometric and co-citation analysis called Bibliometrix. As well as mapping the literature, another theoretical contribution of this study was identifying the main research approaches used in the studies. Within the paradigmatic plurality of social accounting research, the results suggest that social accounting research can also be critically addressed when addressing the sustainability challenges posed by climate change or carbon emissions, among many other aspects. This study is, to our knowledge, the first bibliometric review done about social accounting information disclosure.
\end{abstract}

Keywords: social accounting; voluntary disclosure; social and environmental accounting; social reporting

\section{Introduction}

The last decades have seen a continuous debate globally, notably at the United Nations on social and environmental issues (UNWCED 1987; UN 2015, 2016). Furthermore, more specifically, on the fact that companies are more committed to social responsibility and include the impacts of their activities on these issues in their operational management and global strategy. This means that, in addition to generating profit, they are expected to create 
value and contribute to the global value chain. In this context, the role of accounting in promoting sustainable development has gained in relevance (Bebbington and Unermen 2018). In conceptual terms, social accounting is covered in Social and Environmental Accounting (SEA). The SEA is implicitly linked to companies' contribution to present and future sustainability on a global level. Thus, social issues, among others, have begun to be included in the sustainable development agenda, which has led most companies to adopt the integration and dissemination of sustainability practices in their strategy, based on the triple bottom line (economic, social, and environmental dimension). In this context, many companies have integrated environmental and social management policies into their management accounting systems and have increased their disclosure practices (Larrinaga-González and Bebbington 2001). This propensity/trend towards implementing new specific fields of management accounting and its dissemination to all interested parties has sparked greater interest from social science researchers since the early 1970s (Bebbington and Gray 2001). In the 1990s, interest in social accounting reemerged, with significant concern in the public sector (government) and the private sector (business) with the global social impacts and the environment, such as human rights, ethics, conduct, and values and quality of life. In this context, several proposals have emerged for social accounting to be integrated into companies and other organizations' accounting and management systems. In addition, the attitude of companies towards the disclosure of this type of non-financial information may be related to the organizational culture and type of activity, as well as to existing legislation, since the disclosure of social sustainability reports represents a means of managing and meeting the expectations of stakeholders in general (Rodrigues and Mendes 2018). So, current trends indicate that companies are choosing a new way to communicate social and environmental issues (Bebbington and Gray 2001; Larrinaga et al. 2002). Given this scenario, the Social Accounting disseminated by Ramanathan (1976) stands out, which postulates the disclosure of relevant information on the company's objectives, its economic and financial performance, policies, and social contributions and advocates this through reports that observe the relationship between the cost and benefit of disclosure, prioritizing the mitigation of asymmetry of information between users (Niyama and Silva 2014).

The theoretical framework of this theme is essentially focused on three theories: the theory of legitimacy, the theory of stakeholders (stakeholders' theory) and institutional theory, all of which are widely used in social accounting research, namely, to explain what drives organizations to disclose social and environmental information (Deegan 2014).

Stakeholder theory has been one of the most widely used social accounting theories (Gray 2010). There are two strands to this theory, a normative strand that prescribes how companies/organizations should interact with their stakeholders and a managerial strand that seeks to explain how companies/organizations interact effectively with their stakeholders (Deegan 2014). In the first strand, it is considered that organizations must be accountable to their stakeholders. In the second, the organization must first define who the most important stakeholders are, control the resources, and then make efforts to provide them with the necessary information. In other words, organizations tend not to care about the least essential stakeholders (Deegan 2014). Like the stakeholder theory, the theory of legitimacy considers the organization part of a comprehensive social system (Deegan 2019).

However, while the theory of legitimacy is concerned with the expectations of society at large, it sees a social pact between the organization and the society in which it operates (Deegan 2002). Stakeholder theory focuses on stakeholder groups. Thus, according to the legitimacy theory, companies/organizations survive if the society in which they operate realizes that they contribute to society's global value creation chain (Gray et al. 1996). This theory is based on the concept of organizational legitimacy. This means that legitimacy is a general assumption that an entity's actions/attitudes can be appropriated to society by building a system of norms, values, and boundaries according to the system of that society (Suchman 1995). Therefore, the theory of legitimacy allows explaining and understanding why companies adopt the practice of disclosing their social information, either in social reports or as part of their annual financial reports. Society is an interested party in compa- 
nies' sustainable behavior and, as such, exerts pressure for them to adopt good practices to obtain external and internal legitimacy and, thus, continue to develop their activities successfully. The theory of legitimacy has similarities with institutional theory. Some authors (Deegan 2014) even claim that institutional theory provides additional insight into how organizations understand and respond to changes brought about by social and institutional pressures and expectations. Stakeholder and legitimacy theories suggest that organizations carefully and deliberately plan to disseminate information to meet more powerful stakeholders or the wider community's expectations. Institutional theory, in turn, suggests that, in the absence of a clear justification for doing so, firms disseminate information because their peers do so or because it has become a common practice in the contexts in which they operate, thus introducing a process of homogenization of practices through institutional isomorphism (DiMaggio and Powell 1983). Thus, the institutional theory makes it possible to understand why the dissemination of information happens and how it happens (Higgins and Larrinaga 2014). It also makes it possible to relate organizational practices to the values of the society in which the organization operates and the need to maintain organizational legitimacy. Thus, according to Deegan (2014), institutional theory complements the explanations given by the theories of related parts and legitimacy, allowing the explanation of some asymmetry of information that was still occurring in the elaboration of social reports.

As for the topicality and timeliness of this work, they stem from several reasons. Firstly, the research carried out on this theme showed that, although three articles reviewed the literature, none of them included the dissemination of social information in the themes addressed. Secondly, it was found that most of the literature on the theme under study is scattered and, consequently, in need of systematization. Finally, given the role that social accounting plays in the current business environment, namely, in the international context, its study becomes relevant also in academic terms. This scarcity of studies on disseminating social accounting is the driving force in the first stage of theoretical development on a topic since literature reviews aim to provide in-depth research on a specific field (Mentzer and Kahn 1995; Seuring and Müller 2008).

Accounting research has been fertile in bibliometric analyses, for example Merigó and Yang (2017) proceeded to systematize the state of the art in accounting, in which it identified research that addressed social accounting in its various aspects. Another study mapped the literature on social responsibility in the mining industry (Rodrigues and Mendes 2018); Erkens et al. (2015) thoroughly analyzed non-financial information; Kulevicz et al. (2020) studied how sustainability reports address socio-environmental and business issues; Sikacz (2017) systematized the publications on corporate social responsibility (CSR) reporting.

However, previous studies on the dissemination of social accounting have not included the epistemological paradigms that guide them, so the objectives of this article are to map the literature on social accounting and its dissemination, use the bibliometric method, and identify the main theoretical currents and the research paradigms used and frame them in the taxonomy of Hopper and Powell (1985). In accordance with Hopper and Powell's taxonomy (Hopper and Powell 1985) which, based on the epistemological and ontological assumptions of the researcher, points to three distinct research paradigms in management accounting, which are: positivist research (mainstream), interpretative research and critical research.

Following this brief introduction, the literature review, methodology, results and conclusions are presented.

\section{Literature Review}

Accounting can be used to communicate a company's performance to all stakeholders (Riahi-Belkaoui 2004). This information can be reported through formal and/or informal accounting mechanisms, whether formal reports (financial reports) or informal/voluntary reports (sustainability reports) (Buhr and Reiter 2006). Accounting is only one and, in this context, it is difficult to draw a line between financial accounting, social accounting, and 
environmental accounting (Cooper et al. 2005). However, with social and environmental impacts becoming more evident, the role played by sustainability has become hardcore in several contexts. In this sense, sustainability research has emerged significantly in academia, so Bebbington and Larrinaga-González (2014) have explored the possibilities of building a sustainability-driven accounting system, suggesting two lines of research: sustainability and total cost accounting, and sustainable consumption/production. Historically, Bebbington and Gray (2001) noted that social accounting became an emerging research topic from the 1970s, reflecting its importance for economic growth (Jones 2003). In addition, social and environmental issues and their performance, have begun to be taken into account in corporate management strategies (Gray 2002). However, during the 1980s and 1990s, interest in social and environmental reporting increased (Adams 2002). It has been found that internal factors, such as ethics and transparency, influence the type of information disclosed in companies. In this period, some regulation on these issues has emerged that has institutionally obliged companies to report information on their social and environmental policies (Adams 2002).

These regulations are intended to establish some standardization in corporate reports, so Bebbington et al. (2012) carried out a comparative study between two countries (Spain and the United Kingdom), with different regulations, which concluded that the legitimacy provided by-laws is crucial for the construction of standardization, and also provided a more subtle set of considerations for understanding the role of regulation in these reports. In this area, the literature has focused on some specific themes, such as social and environmental accounting (e.g., Herbohn 2005; Larrinaga-González et al. 2001), the impacts of legislation (e.g., Deegan and Blomquist 2006; Larrinaga et al. 2002), the dissemination of social and environmental information (e.g., Patten 2005), and the relationship between the dissemination of such information and performance (e.g., Adams 2004). For Moser and Martin (2012), many companies are trying to project an image of commitment to social accounting by voluntarily including additional information in their annual financial reports and demonstrating that they create value for all stakeholders and not just the shareholder. This issue arises mainly in large economic groups. The transfer of social accounting practices between countries voluntarily, with differentiated regulations, implies financial investment, an alignment of values, with added advantages for host countries (Bansal 2005). The advantages inherent in this situation are visible in the strengthening of the transparency, reputation and legitimacy of these economic groups in the global business environment (Bansal 2005) and improving the relationship with all stakeholders.

In this context, organizations must communicate information according to stakeholders and show that their information systems, particularly their accounting systems, are appropriate for providing final outputs on social accounting (de Lima Voss et al. 2017). The dimensions included in social accounting (SEA) reflect that businesses contribute to a country's wealth and economic growth and its social and environmental sustainability (Dahlsrud 2008). Thus, for Jennifer Ho and Taylor (2007), there is an awareness that large economic groups of the imperative need to report on these issues and their social performance, whether through voluntary or mandatory disclosure. Social accounting issues can thus be seen from two perspectives. The first relates to the fulfilment of the subsequent responsibilities and obligations of companies.

In contrast, the second relates to the management of the interests of the various stakeholders and represents a means of obtaining internal and external legitimacy (Murray et al. 2006). On the other hand, social accounting has more impact. It is better evidenced in companies carrying out activities with adverse effects on society in general and the environment (Liu and Anbumozhi 2009), as they have greater public exposure (Reverte 2009). However, other factors influence social reporting. Some authors (Lu and Abeysekera 2014; Van de Burgwal and Vieira 2014; Huang and Kung 2010) have shown that the size of the company, its financial profitability, the influence of stakeholders, external controls (audits), influence the implementation of a social accounting information system. 
In short, social accounting is a broad term, including concepts such as corporate social responsibility (CSR), social responsibility accounting (CRA), SEA, reporting and its disclosure, as well as its auditing (Gray et al. 2009). This means that companies tend to promote strategies that incorporate social accounting (SEA) in conjunction with CSR as part of their objectives (Brown and Fraser 2006). However, in terms of practical actions in the surrounding environment and society, these tend to be barely visible (Sikka 2010). This argument does not prevent social accounting from fostering dialogue and commitment with all stakeholders, and there must be a common language and plurality of issues to be discussed (Bebbington et al. 2007; O'Dwyer 2005). Recently, some authors (Adedeji et al. 2018) have argued that it is crucial to determine the influence of corporate governance on companies' sustainability through the initiatives they implement and their association with performance. This means that social accounting is gaining importance for companies. However, most of the evidence gathered in the articles reviewed by Patten and Shin (2019) suggests that sustainability disclosure remains incomplete, biased, and driven by legitimacy concerns. These authors argue that better regulation is needed, including implementing the disclosure of entities' social and environmental information.

Finally, Table 1 shows the studies considered essential/gurus when researching social accounting.

The most studied themes in the 1970s to 1990s are theorization/conceptualization around social accounting, the disclosure of its information and the motivations for doing so. These themes show a cause-effect relationship between them, which means that firstly, it is necessary to define the concepts inherent to social accounting, understood as a new area of accounting. Next, it is necessary to understand how important it is for companies to obtain legitimacy before all stakeholders, which has a positive effect on its disclosure (voluntary or otherwise) and on the motivation of managers/companies to include it in their social performance reports. Nevertheless, these remain of exponential interest to academics, as it is intended to demonstrate in the following sections.

Table 1. Important previous research.

\begin{tabular}{|c|c|c|c|}
\hline Author(s) & Type of Study & Objective & Conclusions \\
\hline \multicolumn{4}{|c|}{ Reviews and concepts in social accounting research } \\
\hline Gray (2002) & Theoretical & $\begin{array}{l}\text { Review of the literature over the last } 25 \\
\text { years on social accounting, in particular } \\
\text { articles published in the journal } \\
\text { Accounting Organizations \& Society. }\end{array}$ & $\begin{array}{l}\text { Social accounting, as a promising area of } \\
\text { accounting research, should make more use of its } \\
\text { theoretical wealth, and more articles should be } \\
\text { published on the commitment it involves. }\end{array}$ \\
\hline $\begin{array}{l}\text { Rubenstein } \\
(1992)\end{array}$ & Theoretical & $\begin{array}{l}\text { Build the bridge between green } \\
\text { accounting and traditional accounting. }\end{array}$ & $\begin{array}{l}\text { Given the existence of natural resources that are } \\
\text { crucial for global economic growth, it is } \\
\text { pertinent to create accounting that allows the } \\
\text { recording of their degradation in the financial } \\
\text { statements of the companies that exploit them. } \\
\text { This means that accounting will reflect a new } \\
\text { social contract between all stakeholders, which } \\
\text { goes beyond traditional accounting. }\end{array}$ \\
\hline $\begin{array}{l}\text { Bebbington and } \\
\text { Gray (2001) }\end{array}$ & Empirical & $\begin{array}{l}\text { Through Social Cost Calculation (SCC) } \\
\text { they aim to measure the additional } \\
\text { costs that companies incur to be } \\
\text { sustainable throughout their lifetime in } \\
\text { accounting terms. }\end{array}$ & $\begin{array}{l}\text { Although it is a specific case study, they } \\
\text { concluded that this was useful in understanding } \\
\text { where the implementation of the SCC failed so } \\
\text { that it can be avoided in future implementations. }\end{array}$ \\
\hline $\begin{array}{l}\text { Cooper and } \\
\text { Sherer (1984) }\end{array}$ & Theoretical & $\begin{array}{l}\text { Presentation of an alternative scheme } \\
\text { for carrying out research in } \\
\text { corporate accounting. }\end{array}$ & $\begin{array}{l}\text { Accounting research in the economic, social and } \\
\text { environmental dimensions should use an } \\
\text { alternative approach (normative, descriptive and } \\
\text { critical), particularly in the last two dimensions } \\
\text { that are of interest to all stakeholders and not } \\
\text { only the shareholder. }\end{array}$ \\
\hline
\end{tabular}


Table 1. Cont.

\begin{tabular}{llll}
\hline Author(s) & Type of Study & Objective & Conclusions \\
\hline Gray (1992) & Theoretical & $\begin{array}{l}\text { Bridging the gap in the literature on } \\
\text { natural environment research. }\end{array}$ & $\begin{array}{l}\text { Previous research has provided little informative } \\
\text { detail on a new accounting that responds to the } \\
\text { interests of social and environmental issues. } \\
\text { They highlight some contributions to the } \\
\text { creation of such accounting, as it is profoundly } \\
\text { difficult to begin to rebuild the world on the } \\
\text { basis of financial/accounting practices. }\end{array}$ \\
\hline
\end{tabular}

Gray et al. (1997) Empirical

Understanding of the theoretical and practical issues of social accounting, taking stakeholders into consideration.

Understanding of what the concept of Gray (2010) Theoretical sustainability can mean for accounting and finance.

Address the functional gap in the FASB, (Financial Accounting Standards Board)

Hines (1991) Theoretical conceptual framework based on anthropology, between accounting and economic reality.

Neu et al. (1998) Empirical $\quad \begin{aligned} & \text { Study of the role of environmental } \\ & \text { reporting in the mining industry. }\end{aligned}$

The social accounting agenda remains open and is a dynamic process that requires commitments. Thus, it is crucial that the academic community continues to research it and that the necessary theoretical and practical changes are promoted.

They have compiled the speculation around how to move towards sustainable accounting, which is a challenge.

They aimed to facilitate demythologising between reason and objectivity as a means of facilitating critical, constructive and social research in the field of accounting.

The reports show social and environmental information, but it is very aggregated and it is not possible to see the actions taken by the companies.

\section{Legitimacy vs. disclosure of social accounting}

\begin{tabular}{|c|c|c|c|}
\hline Patten (1992) & Empirical & $\begin{array}{l}\text { To examine, based on legitimacy theory, } \\
\text { the effects of oil companies' spillages, } \\
\text { i.e. their inclusion in their } \\
\text { annual reports. }\end{array}$ & $\begin{array}{l}\text { There has been a significant increase in these } \\
\text { disclosures, which has a positive relationship } \\
\text { with company size and capital holders. This } \\
\text { means that when the legitimacy of the company } \\
\text { is called into question, they include more social } \\
\text { and environmental information in their } \\
\text { annual reports. }\end{array}$ \\
\hline $\begin{array}{l}\text { Dowling and } \\
\text { Pfeffer (1975) }\end{array}$ & Empirical & $\begin{array}{l}\text { To provide a conceptual framework for } \\
\text { the analysis of organizational } \\
\text { legitimacy and the process of } \\
\text { obtaining it. }\end{array}$ & $\begin{array}{l}\text { They concluded that legitimacy provides a } \\
\text { means to analyze the behaviors that } \\
\text { organizations engage in as they vary according } \\
\text { to their environment and their own values. }\end{array}$ \\
\hline Wiseman (1982) & Empirical & $\begin{array}{l}\text { Assessing the quality and accuracy of } \\
\text { the disclosure of environmental } \\
\text { information included in companies' } \\
\text { annual reports. }\end{array}$ & $\begin{array}{l}\text { It concluded that the disclosure of this } \\
\text { information is incomplete and does not report on } \\
\text { environmental performance. }\end{array}$ \\
\hline \multicolumn{4}{|c|}{ Motivations for disclosing social accounting } \\
\hline Hirshleifer (1971) & Empirical & $\begin{array}{l}\text { Analysis of the economic information } \\
\text { that individuals possess, but } \\
\text { incomplete, i.e. they only have } \\
\text { information about } \\
\text { market opportunities. }\end{array}$ & $\begin{array}{l}\text { He concluded that it is crucial to have public and } \\
\text { private information about the market and } \\
\text { its environment. }\end{array}$ \\
\hline Verrecchia (1983) & Empirical & $\begin{array}{l}\text { Presentation of a case, where the } \\
\text { information to be disclosed is risky. } \\
\text { associado, pelo que deve } \\
\text { ser discricionária. }\end{array}$ & $\begin{array}{l}\text { It shows how the existence of costs to be } \\
\text { disclosed in excess of stakeholder expectations } \\
\text { provides a motivation to withhold such } \\
\text { unfavorable information. }\end{array}$ \\
\hline
\end{tabular}




\section{Methods}

This article's research methodology consists of a bibliometric review (analysis of co-citations) using the R software. Bibliometrix (Aria and Cuccurullo 2017). It is a study based on co-citation networks and content analysis (by reading all articles). This type of approach has as its unit of analysis the scientific articles (in this case, the research focused only on scientific articles) and consists of a grouping of documents with a common goal and hardcore (Grácio 2016). This type of analysis provides the identification, evaluation, and analysis of content in specific areas and systematization of concepts, theories, and practices (Rowley and Slack 2004). Content analysis is a research tool aimed at analyzing and systematizing data for replication, with the selection of the data to be analyzed being crucial (Krippendorff 1980) and data collection in this study, followed the common research procedures, through the ISI Web of Science (WoS) search engine to ensure their reliability, since this engine ensures real-time data availability (Krippendorff 2004, 2012). This means that it is a compilation of scientific documents and their contributions, as it brings critical added value and provides a synthesis of the literature on the topic under study and the identification of relevant gaps and clues for future research purposes. Its main objective is to contribute to the advancement of scientific knowledge on this topic by identifying patterns of subtopics, authors, scientific journals, citations, co-citations, keywords, among others (Prasad and Tata 2005; Treinta et al. 2014); and conceptual contents (Seuring and Müller 2008).

This analysis also followed the methodological procedures defined by Tranfield et al. (2003): planning; development; and presentation of results. In this context, the bibliometric analysis of a specific area of research implies adopting a methodical and structured research strategy for the selection of the documents to be included in the respective literature systematization. Thus, it is crucial to define the criteria and keywords to be used in the process of enquiry and specification of documents (Bandara et al. 2011), and therefore the delimitation of the literature search process is fundamental to obtain an appropriate link between the main topic and subtopics and then proceed to their descriptive analysis (Quesado and Silva 2021; Treinta et al. 2014).

Table 2 presents the criteria used in the October 2020 survey.

Table 2. List of Items and Search Criteria.

\begin{tabular}{ll}
\hline \multicolumn{1}{c}{ Items } & \multicolumn{1}{c}{ Criteria } \\
\hline Time horizon: & No chronological filter \\
\hline Online databases: & ISI (WoS) \\
\hline Keywords: & Social and CSR accounting and disclosure \\
\hline Serialization by search category: & Management or Corporate Finance or Economics or \\
& Environmental Studies or Environmental Sciences \\
\hline Serialization by type of document: & Articles \\
\hline Software used: & R. Bibliometrix \\
\hline Documents analyzed: & 126 \\
\hline
\end{tabular}

After obtaining the final version of the scientific articles database, the analysis developed through the following steps:

1. Export to BIBText of all the bibliographical data in order to prepare the descriptive analysis of the 126 scientific articles identified on the subject (Table 1), in terms of the type of document, number of citations, distribution by year of publication, authors, countries, research areas, and titles of sources.

2. The bibliometric analysis was performed using the R Bibliometrix software (Aria and Cuccurullo 2017). A set of tools was used to process all data on serial publications for analysis (126 documents). From this processing several outputs can be extracted (e.g., on authors, number of publications, networks, couplings) (Ekundayo and Okoh 2018), 
which result from procedures for standardizing similarity of publications (Aria and Cuccurullo 2017). The R Bibliometrix software is a package for bibliometric analysis written in R. According to Derviş (2019), R is open-source software, which means that it operates in an integrated environment that consists of open libraries, open algorithm and open graphic software. This tool's other strengths are potent and effective statistical algorithms, access to high-quality numerical routines, and integrated data visualization tools (Aria and Cuccurullo 2017). The R Bibliometrix software can be used to analyze and map bibliographic data simultaneously (Derviş 2019). Compared with other open-access programs such as VOSviewer, Bibliometrix focuses on not only data visualization but also the accuracy and statistical robustness of results (Derviş 2019).

3. Enrichment of the bibliometric analysis, through the integration of a content analysis of the 126 selected documents, aiming to systematize the topics/subjects of research most studied by the scientific community and that originated the clusters (Spens and Kovács 2006; Seuring and Gold 2012). However, this analysis of content is somewhat subjective, given its qualitative character. However, this does not impugn the validity of its inferences and their rigor (Becker et al. 2012), so a structured and systematic approach has been adopted to overcome this limitation, as recommended by Tranfield et al. (2003) and Seuring and Gold (2012).

4. Definition of the research paradigms used in published studies, based on the criteria defined by several authors (Orlikowski and Baroudi 1991; Chen and Hirschheim 2004; Dwivedi and Kuljis 2008), namely whether the article uses primary data (empirical study or not); the nature of the empirical study developed (quantitative and qualitative); and the methods used.

\section{Analysis and Discussion of Results}

\subsection{Characterization of the Data Collected}

Before going into the analysis of the data collected, a general characterization of the data collected is presented in Table 3.

Over 15 years, 287 authors have published 126 documents on the dissemination of social accounting information. There is a high level of collaboration in work done. In other words, collaboration among authors appears as a critical factor, and consequently, only eleven authors have published articles individually. The articles analyzed were cited by about 22 authors and have collected more than 3 citations per year.

Table 3. Characteristics of the Data Collected.

\begin{tabular}{ll}
\hline \multicolumn{1}{c}{ Description } & Results \\
\hline TIMESPAN & \\
\hline Sources (Journals, Books, etc.) & 2006 to 2020 \\
\hline Average citations per documents & 3.03 \\
\hline Average citations per year per doc & 21.88 \\
\hline References & 3.767 \\
\hline DOCUMENT TYPES & 6.260 \\
\hline Article & 126 \\
\hline Article and Review & \\
\hline DOCUMENT CONTENTS & 338 \\
\hline Keywords Plus (ID) & 412 \\
\hline Author's Keywords (DE)
\end{tabular}


Table 3. Cont.

\begin{tabular}{ll}
\hline \multicolumn{1}{c}{ Description } & Results \\
\hline AUTHORS & 287 \\
\hline Authors & 306 \\
\hline Author Appearances & 11 \\
\hline Authors of single-authored documents & 276 \\
\hline Authors of multi-authored documents & \\
\hline AUTHORS COLLABORATION & 12 \\
\hline Single-authored documents & 0.397 \\
\hline Documents per Author & 2.52 \\
\hline Authors per Document & 2.68 \\
\hline Co-Authors per Documents & 2.71 \\
\hline Collaboration Index &
\end{tabular}

\subsection{Evolution and Characterization of Scientific Production}

Concerning the temporal evolution of the articles published on the subject under study, Figure 1 shows researchers' growing interest. Thus, there has been a substantial growth from 2015 onwards, with the most productive year for the publication of research articles on social accounting and its dissemination being the year 2018, with 27 publications, and it is now the year 2020, with 27 publications. This means that the subject continues to arouse growing interest in the scientific community.

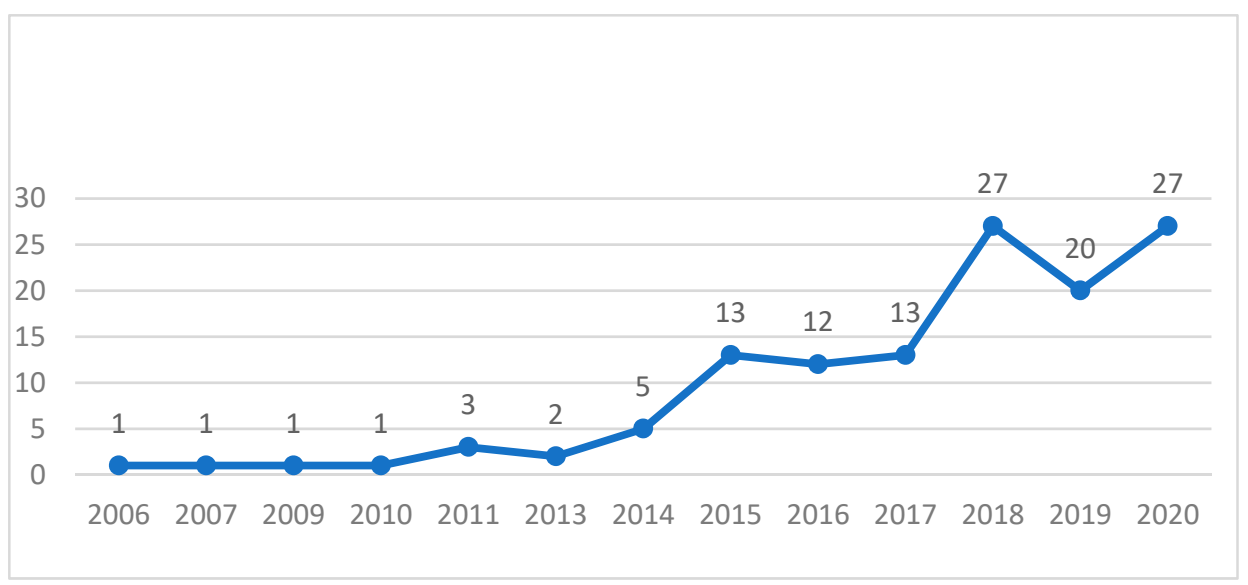

Figure 1. Evolution of the Number of Publications on Social Accounting Disclosures, by Year.

The growth of publications in recent years indicates that this issue has begun to arouse interest and draw attention to social responsibility and the importance of it being disseminated and reported to all stakeholders so that they are endowed with credibility legitimacy both internally and externally. Of course, this legitimacy does not relate to accounting as such, but to the parties involved in its disclosure. It should also be noted that these publications are essentially empirical studies, identifying only two literature review articles, one published in 2015 and one in 2016, and two theoretical articles. The theoretical paper of 2016 shows a recently criticized analysis of the impacts of corporate social responsibility on sustainable human development (Anstätt and Volkert 2016). One of 2015 studies the evolution of social responsibility reporting standards (Tschopp and Huefner 2015). As for empiricists, their main characteristic lies in analyzing published social responsibility reports, in their various items. 
To find out which countries publish more articles on the subject under analysis, Figure 2 shows the relevance of each country in the total of articles analyzed, considering the country of the first author, following the information taken from the ISI WoS.

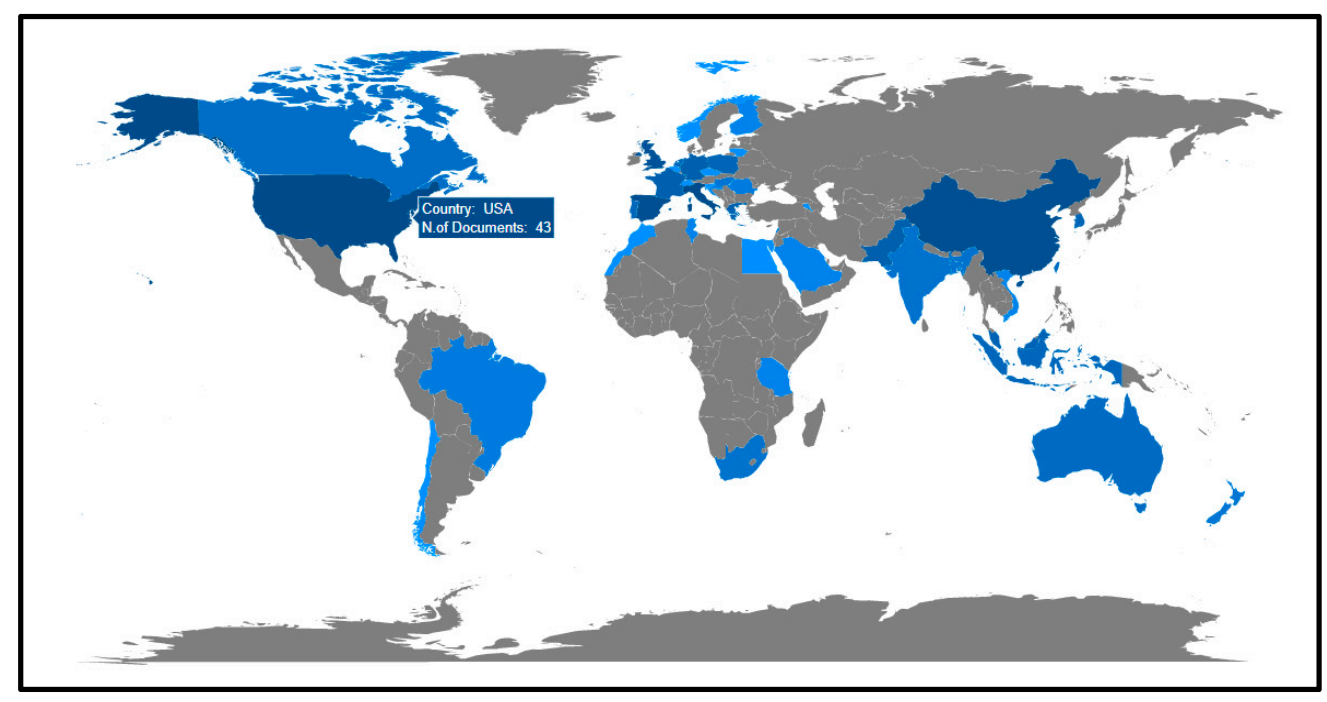

Figure 2. Publications by Country (Country of the first author).

Figure 2 shows the scientific production of the United States of America with 43 publications, Italy (40), China (31), Spain (8), and the United Kingdom (4). In China's case, the interest comes from the importance that the extractive industry has assumed in the economic activity of this country. Here, the negative impacts (e.g., a significant number of accidents in recent years) have triggered the academic world's interest in studying social accounting and its dissemination in this country.

According to the procedures described (first step), the frequency of publications per journal is shown below (Table 4).

Table 4. Journals with the highest number of articles and Web of Science Impact Factor.

\begin{tabular}{lccc}
\hline \multicolumn{1}{c}{ Journal } & Number of Publications & $\mathbf{\%}$ & Impact Factor \\
\hline Sustainability & 14 & $11.11 \%$ & 2.576 \\
\hline $\begin{array}{l}\text { Journal of Business Ethics } \\
\begin{array}{l}\text { Corporate Social Responsibility and } \\
\text { Environmental Management }\end{array}\end{array}$ & 12 & $9.52 \%$ & 1.165 \\
\hline $\begin{array}{l}\text { Sustainability Accounting } \\
\text { Management and Policy Journal }\end{array}$ & 10 & $7.94 \%$ & 0.97 \\
\hline Social Responsibility Journal & 10 & $7.94 \%$ & 0.67 \\
\hline Journal of Cleaner Production & 7 & $5.56 \%$ & 0.43 \\
\hline Journal of Global Responsibility & 5 & $3.97 \%$ & 1.615 \\
\hline Management Decision & 4 & $3.17 \%$ & 0.26 \\
\hline Other (<4 publication each) & 4 & $3.17 \%$ & 0.86 \\
\hline Total & 60 & $47.6 \%$ & \\
\hline
\end{tabular}

The magazine with the largest number of publications is Sustainability magazine. As can be seen in Table 4, it is the journal with the highest impact factor (2.576). The 14 articles published in this journal total 119 citations, with the most frequently cited article (30 citations) by Matuszak and Różańska (2017) being published in this journal. This article addresses the new non-financial reporting requirements implemented through Polish 
accounting legislation (PAA) in 2017, after the transposition of an EU directive. This study portrays the analysis carried out in the reports of 150 listed companies after implementing this legislation.

It is also noted in Table 4 that we have four journals: Sustainability, Journal of Business Ethics, Corporate Social Responsibility and Environmental Management, and Sustainability Accounting Management and Policy Journal, which concentrate 36.5\% (46 articles) of the publications. This does not prevent some dispersion in the publication of this type of work, since there is also a significant group of journals (60) less than three publications. This group of 60 includes the Accounting Review journal, with an impact factor of 5.45 and the article by Soana (2011) reflected in the Table 5 .

Table 5. Most Cited Articles in the Web Database of Science.

\begin{tabular}{|c|c|c|c|c|}
\hline Authors & Journal & Year & $\begin{array}{l}\text { Number of } \\
\text { Citations }\end{array}$ & $\begin{array}{c}\text { Annual Average } \\
\text { Citations }\end{array}$ \\
\hline Reverte & Journal of Business Ethics & 2009 & 387 & 32.25 \\
\hline López, Garcia, \& Rodriguez & Journal of Business Ethics & 2007 & 255 & 18.214 \\
\hline $\mathrm{Kim}, \mathrm{Li}, \& \mathrm{Li}$ & Journal of Business Ethics & 2006 & 206 & 29.429 \\
\hline Soana & Journal of Business Ethics & 2011 & 110 & 11 \\
\hline Vuontisjarvi & Journal of Banking $\mathcal{E}$ Finance & 2014 & 108 & 7.2 \\
\hline Mallin, Farag, \& Ow-Yong & Journal of Business Ethics & 2016 & 85 & 12.143 \\
\hline Nollet, Filis, \& Mitrokostas & Economic Modelling & 2016 & 71 & 14.2 \\
\hline Chauvey, Giordano-Spring, \& Cho & Journal of Business Ethics & 2015 & 69 & 11.5 \\
\hline Martinez-Ferrero, Garcia-Sanchez & $\begin{array}{l}\text { Corporate Social Responsibility and } \\
\text { Environmental Management }\end{array}$ & 2015 & 65 & 10.833 \\
\hline $\begin{array}{c}\text { Garcia-Sanchez \& } \\
\text { Cuadrado-Ballesteros }\end{array}$ & Long Range Planning & 2010 & 61 & 12.2 \\
\hline Harjoto \& Jo & Journal of Business Ethics & 2015 & 61 & 10.167 \\
\hline Skouloudis, Evangelinos, \& Kourmousis & Journal of Cleaner Production & 2010 & 59 & 5.364 \\
\hline Galant \& Cadez & Economic Research-Ekonomska Istrazivanja & 2017 & 48 & 12 \\
\hline Giannarakis, Konteos, \& Sariannidis & Management decision & 2014 & 46 & 6.571 \\
\hline Tschopp \& Huefner & Journal of Business Ethics & 2015 & 39 & 6.5 \\
\hline Tschopp \& Nastanski & Journal of Business Ethics & 2014 & 37 & 5.286 \\
\hline Mio \& Venturelli & $\begin{array}{l}\text { Corporate Social Responsibility and } \\
\text { Environmental Management }\end{array}$ & 2013 & 36 & 4.5 \\
\hline Reverte & Review of Managerial Science & 2016 & 32 & 6.4 \\
\hline Matuszak \& Rozanska & Sustainability & 2017 & 30 & 7.5 \\
\hline $\begin{array}{c}\text { Perez-Lopez, Moreno-Romero, \& } \\
\text { Barkemeyer }\end{array}$ & Business Strategy and the Environment & 2015 & 28 & 4.667 \\
\hline
\end{tabular}

The following graph (Figure 3) shows each journal's growth over the years, with Sustainability, Journal of Business Ethics, and Accounting, Auditing and Accountability Journal, especially from 2014 onwards.

Furthermore, the authors with the most significant number of publications were sought in the 126 articles analyzed. The author Antonis Skouloudis stands out, with three articles published on the topic under analysis. Two of the articles were published in the Journal of Cleaner Production and one article in the magazine Corporate Social Responsibility and Environmental Management (Khan et al. 2019; Skouloudis et al. 2010; Skouloudis et al. 2014). In Skouloudis et al. (2010), the non-financial report prepared following the GRI-Global Reporting Initiative, Greece, was studied. The results of this study show that improvements 
and more outstanding commitment from stakeholders are still needed. In Khan et al. (2019), corporate social responsibility was addressed from a very particular perspective: people with disabilities. The authors of this study concluded that there is still room for improvement in actions that create the quality of life for these people. In Skouloudis et al. (2014) it was found that, in Greece, the dialogue of large companies with their stakeholders in terms of social responsibility is still very superficial and that only a minority group of companies values this dialogue.

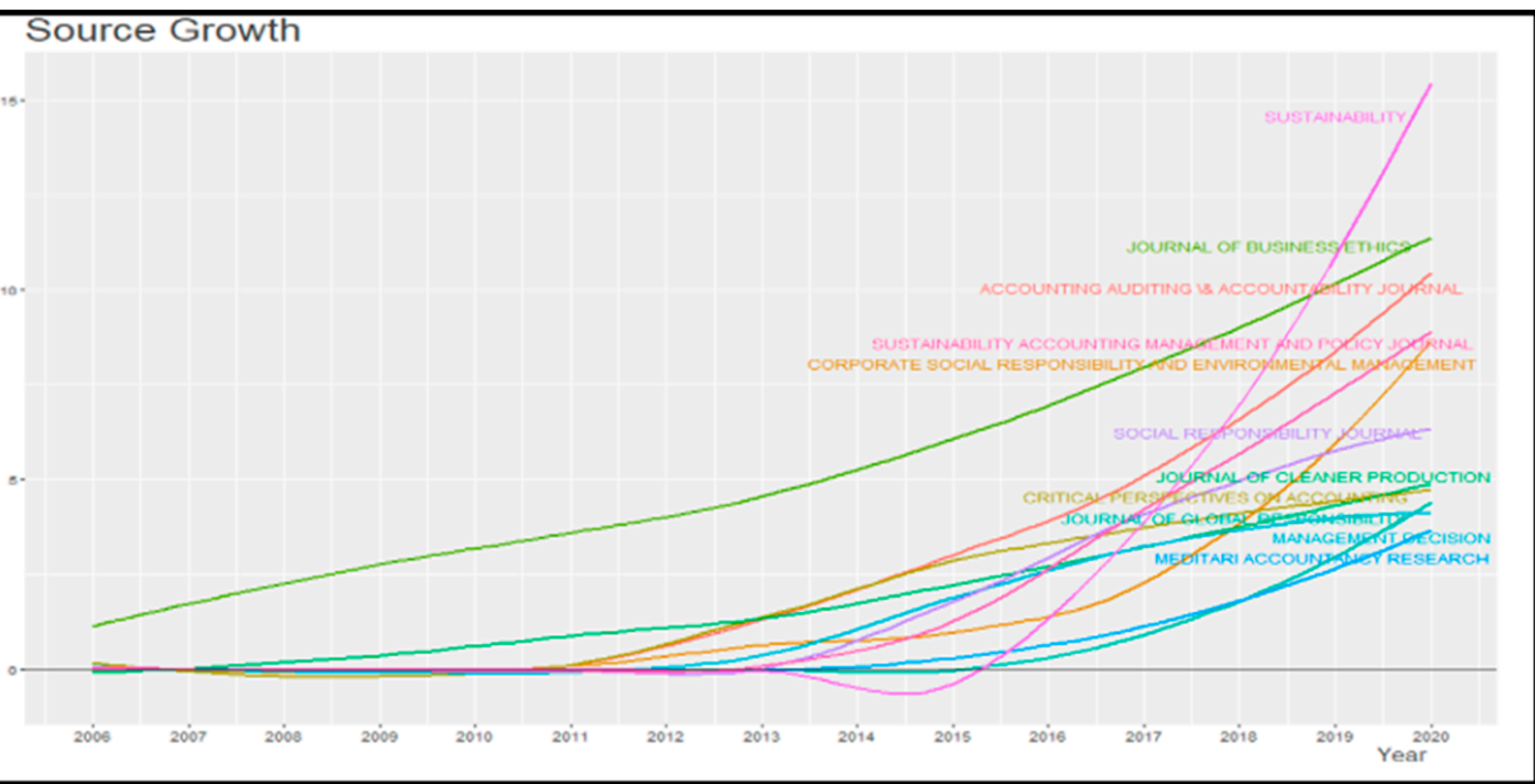

Figure 3. Evolution of Publications, by Year and Journal.

To find out the most relevant works according to the number of citations received by each article, the number of citations and the annual average of citations of the articles were analyzed (Table 5). Although the analysis focused on the 126 articles analyzed, only the 20 most cited articles by other authors are presented here. The Journal of Business Ethics is highlighted here with 8 of the 20 articles in this list. On the other hand, the three papers with the highest number of citations and the highest annual average were also published in this journal (see Table 4). As can be read on the page of the journal itself, the prominence of this journal stems from the fact that social responsibility, social accounting and their disclosure have a significant relationship with the ethical and ontological principles that should guide this particular area of management research.

\subsection{Bibliometric Analysis}

Moving on to stage 2, network analysis is increasingly used for the operationalization of bibliometric studies and metric studies (Jalal 2019). In this context, the Bibliometrix $R$ software allows a network analysis, through algorithmic connections between the various attributes of the database, and an additional analysis-co-citation or coupling networks (Aria and Cuccurullo 2017). These networks are examined to capture the significant properties of the research subject under analysis and, in particular, to determine the influence of bibliometric units, such as authors and keywords (Aria and Cuccurullo 2017). The data collected were downloaded in Bibtex format from Clarivate Analytics' Web of Science (WoS) database. Subsequently, R Studio software version 1.2.5042 was used to eliminate duplications and to create a unified database. This process resulted in the 126 documents that we have analyzed in this work. 
From an analysis of keywords, it was possible to see that specific themes tend to appear related to each other, forming clusters, i.e. densely grouped sets of terms in publications on this theme. We used a factorial analysis to create a map/conceptual structure from a multiple correspondence analysis (MCA). We can see how different concepts are correlated in the analyzed studies (Figure 4). This technique searches for possible keywords in the data records and applies multiple matching analysis (MCA) to the identified keywords. However, irrelevant keywords may occasionally appear.

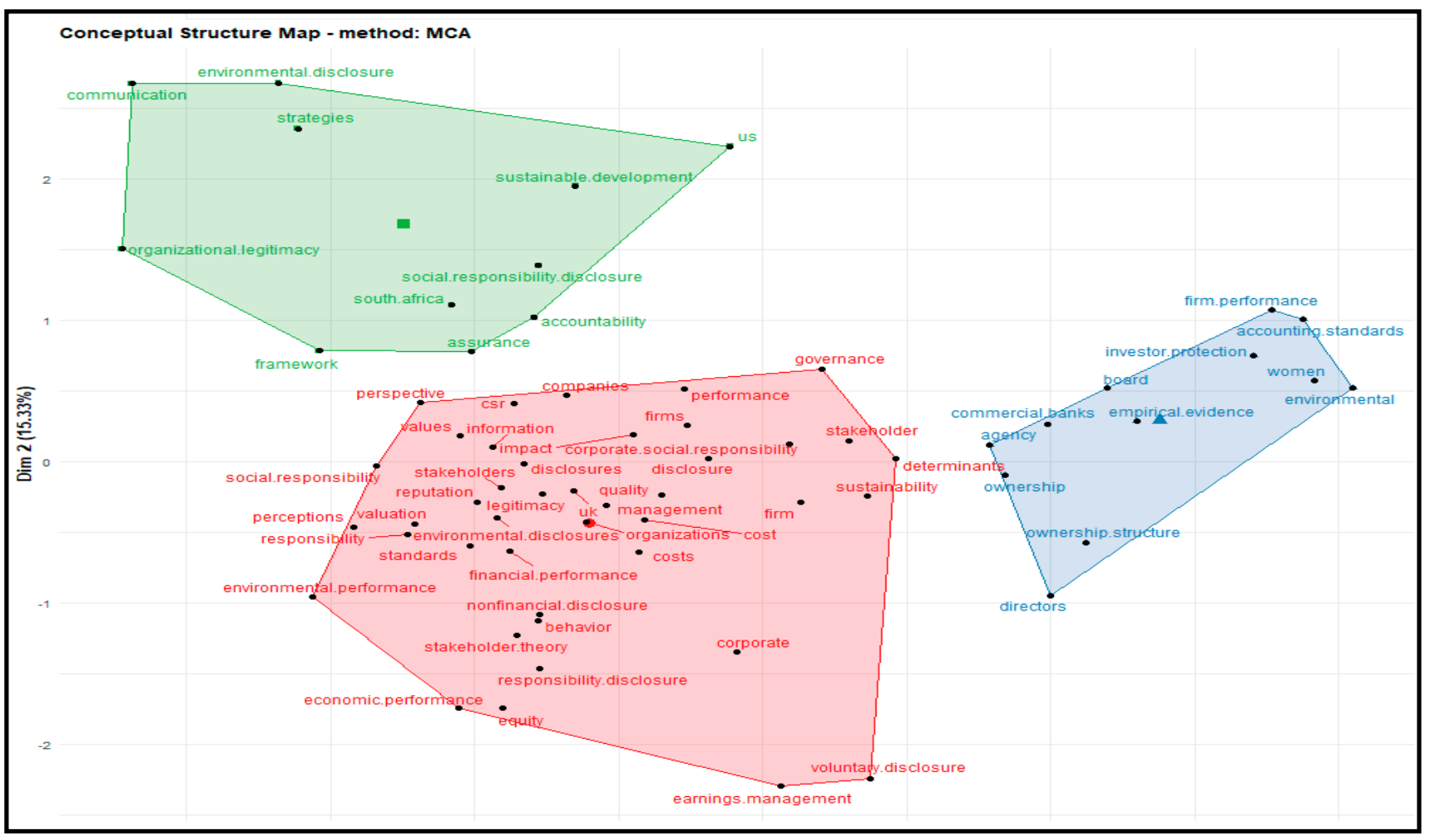

Figure 4. Conceptual Structure Based on the Correlation between Words ( $n=126$ documents).

This technique identifies research trends in social accounting and its dissemination, and there are three distinct clusters (three colors). Thus, from the analysis of the keywords, it is possible to create or identify a potential conceptual structure on the subject, as shown in Figure 4.

It can be seen that the largest cluster (red) addresses issues related to stakeholder theory and some issues of legitimacy and environmental reporting, voluntary or not, for stakeholders. The issues of financial and non-financial reporting, the linkage of voluntary reporting to the manipulation of results or the study of voluntary reporting determinants are addressed here. The relationship between economic performance and environmental performance is also analyzed here.

The second (green) cluster explores issues associated with disseminating information on social responsibility and the importance of communication in social and environmental reporting. The characteristics of communication on organizational legitimacy are also analyzed.

Finally, in the third cluster, themes associated with disseminating social and environmental information more focused on the company, the characteristics of the management team, the ownership structure, and the protection of shareholders emerge.

Complementary to this figure is a network of co-quotes between authors (Figure 5) that allows identifying the most relevant works and authors cited by more authors, highlighting, among others, the article by Gray et al. (1995) and the classical works by Freeman (1984), Waddock and Graves (1997), and Deegan (2002). 


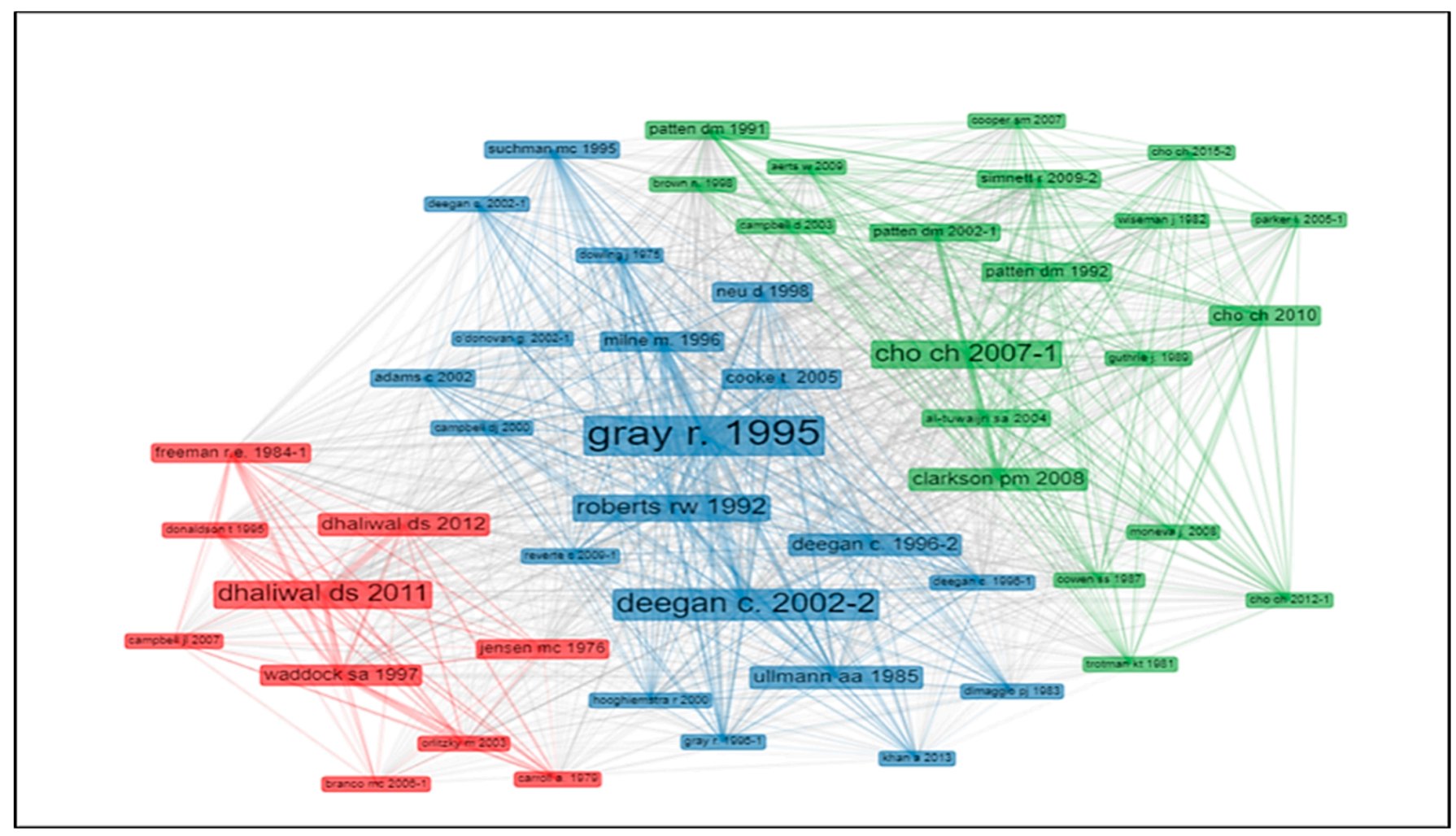

Figure 5. Bidding Network ( $n=126$ documents).

Three major groups or clusters of authors are also evident here. The first with work related to the issues of legitimacy and disclosure of information on social accounting (blue), the second with work related to the issues of disclosure of information on social accounting (green), and the third focusing on the motivations leading to the disclosure of information on social accounting.

In order to visualize the existing network of scientific collaboration between academics/authors, most studied topics, and journals/journals where the outputs are published, a graph of three fields or Sankey's Diagram (Figure 6) was used, which allows the visualization of the prominent authors, topics (keywords) and international journals where the publications were made. The representation of the network in graphic format facilitates the visualization of the interactions between the three fields analyzed. In this graph, the larger the size of the colored rectangles, the greater the frequency/importance of a given magazine, keyword, or author in the collaboration network. In addition, the links (the lines connecting institutions, keywords, and authors) vary in thickness depending on the number of links. In this context, the graph shows that themes such as "performance", "corporate social responsibility", "governance", and "environmental disclosures" are the ones that generate the most significant collaboration between academics from different institutions. Among the essential authors/papers are Gray et al. (1995); Deegan (2002); Roberts (1992); Cho and Patten (2007); Dhaliwal et al. (2011); Waddock and Graves (1997). Concerning journals, Sustainability, the Journal of Business Ethics and the Journal of Cleaner Production stand out. In terms of topics, performance studies, legitimacy, corporate social responsibility, and environmental reporting are highlighted. 


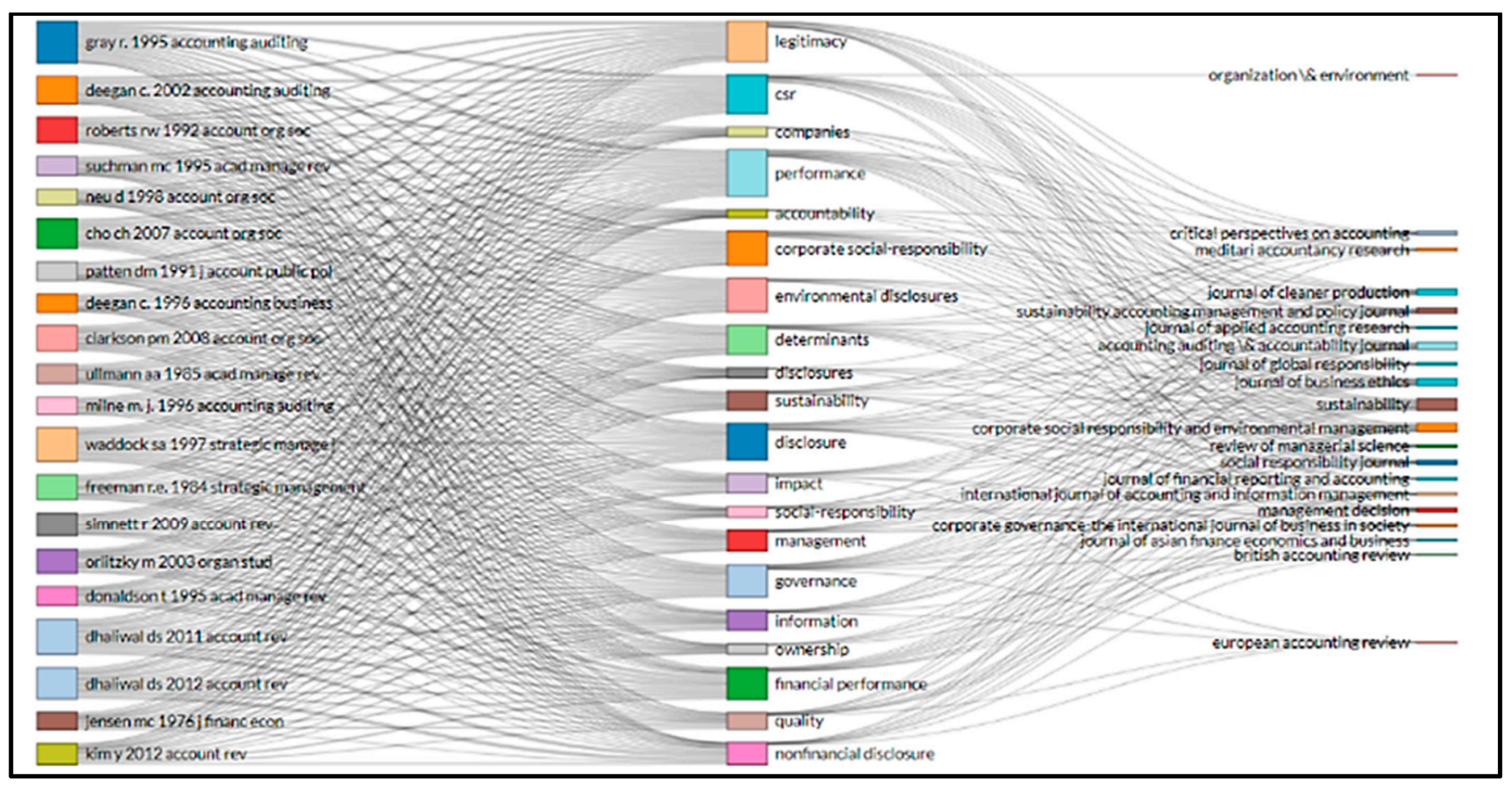

Figure 6. Collaborative network between authors (left), topics (center) and subsequent publication in a journal (right).

\subsection{Analysis of the Most Relevant Work}

The content of the most relevant work highlighted in each of the clusters identified above was then analyzed. In this context, it is also important to understand the relevance of social accounting in the legitimization of companies' actions and to understand which factors positively affect disclosure (voluntary or not) and on the motivation of managers/companies to include information in their social performance reports. It was also found that the disclosure of information on social accounting is crucial for companies to gain credibility with all stakeholders.

It should be noted that the studies covered in this review have a diversified theoretical framework that includes the theory of legitimacy, stakeholder theory, and institutional theory. This is justified because social accounting is a new area of research that provides intangible benefits to organizations, even if there is some asymmetry of information, which is reflected positively in their financial results and creates value for shareholders and other stakeholders.

Linking the work identified in Figure 5 with the analysis of the main articles developed in Table 6, it can be seen that in the first group we find work framed in the theory of legitimacy (Gray et al. 1995), namely, in the way the search for legitimacy explains the voluntary disclosure of information by companies (Deegan 2002). Here we also find work based on stakeholder theory, namely to explain how stakeholders' power conditions the dissemination of information and CSR practices (Roberts 1992). In the second group, we find work framed in stakeholder theory (Freeman 1984) and focused on the issues of disclosure of information to stakeholders and the impact this voluntary disclosure has on the value of the company (Dhaliwal et al. 2011) and financial analysts' forecasts (Dhaliwal et al. 2012). The third group includes studies that sought to study why companies disclose social accounting information (Cho and Patten 2007) and research the use of language and tone to mask poor performance (Cho et al. 2015).

A further reading of the above table compared to Table 1 shows that the topics highlighted in the latter remain a fertile theme as evidenced in clusters 1 to 3 . 
Table 6. Analysis of content per cluster (based on the work shown in Figure 5).

\begin{tabular}{|c|c|c|c|}
\hline Author(s) & Type of Study & Objective & Conclusions \\
\hline \multicolumn{4}{|c|}{ Cluster 1: Legitimacy vs. social accounting disclosure (blue) } \\
\hline Gray et al. (1995) & Empirical & $\begin{array}{l}\text { Interpretation and understanding of the } \\
\text { CSR in the UK and its dissemination, in } \\
\text { the light of various theoretical } \\
\text { frameworks, such as the theory of } \\
\text { legitimacy and stakeholder theory. }\end{array}$ & $\begin{array}{l}\text { The conclusion is limited to the geographical } \\
\text { context of the study. However, they call for } \\
\text { homogenization of practices, both at the level of } \\
\text { action and dissemination. }\end{array}$ \\
\hline Deegan (2002) & Theoretical & $\begin{array}{l}\text { Introduction to a particular volume of the } \\
\text { Accounting, Auditing \& Accountability } \\
\text { Journal on social and environmental } \\
\text { reporting, its role in legitimacy, and its } \\
\text { dissemination motivations. }\end{array}$ & $\begin{array}{l}\text { It concludes that the theory of legitimacy is widely } \\
\text { used to explain the motivations for disseminating } \\
\text { this type of information; these motivations are } \\
\text { significantly related to the legitimacy that they } \\
\text { intend to obtain/maintain for the } \\
\text { activity performed. }\end{array}$ \\
\hline Roberts (1992) & Empirical & $\begin{array}{l}\text { Explanation of corporate social } \\
\text { responsibility practices, based on } \\
\text { stakeholder theory. }\end{array}$ & $\begin{array}{l}\text { It concludes that this theory explains the need for } \\
\text { these practices. The measurement of stakeholder } \\
\text { power, strategic stance, and economic performance } \\
\text { affect the amount of information disclosed } \\
\text { about them. }\end{array}$ \\
\hline
\end{tabular}

Cluster 2: Disclosure of social accounting information (red)

Dhaliwal et al. (2011) Empirical Analysis of the impact of voluntary

Dhaliwal et al. (2011) Empirical environmental disclosure on business value

They concluded that when a company starts voluntarily disclosing CSR, there is a reduction in the cost of equity. However, they perform well on social responsibility vis-à-vis non-initiated companies. Thus, a potential reduction in equity cost can be a motivating factor for companies to publish social reports autonomously.

They argued that the disclosure of non-financial information is linked to better environmental

Study on the relationship between

Dhaliwal et al. (2012) Empirical financial and non-financial disclosure and the accuracy of analysts' profit forecasts. information and the fact that it complements the disclosure of financial information, which mitigates the negative effect of the financial opaqueness of the accuracy of the forecasts.

They argued that this link is visible because the existence of financial leeway for the availability of resources for the CSR is positively associated with the financial result.

$\begin{array}{cc}\text { Waddock and Graves } & \text { Empirical }\end{array} \begin{gathered}\text { Study of empirical links between social } \\ \text { and financial performance. }\end{gathered}$

Orlitzky et al. (2003) Empirical
Presentation of a meta-analysis of primary quantitative studies on social and financial performance.
They showed that social performance is positively correlated with financial performance. This relationship tends to be two-way, that reputation is an important mediating factor for disclosure to stakeholders.

\begin{tabular}{|c|c|c|c|}
\hline \multicolumn{4}{|c|}{ Cluster 3: Motivations/Reasons for the disclosure of social accounting (green) } \\
\hline $\begin{array}{l}\text { Cho and Patten } \\
\qquad(2007)\end{array}$ & Empirical & $\begin{array}{l}\text { Seeking to analyze the motivations that } \\
\text { lead companies to disclose information, } \\
\text { these authors will investigate whether } \\
\text { social and environmental reporting is a } \\
\text { tool for legitimacy. }\end{array}$ & $\begin{array}{l}\text { They conclude that companies use the disclosure } \\
\text { of environmental information in financial } \\
\text { reporting as a tool for legitimization. }\end{array}$ \\
\hline Cho et al. (2010) & Empirical & $\begin{array}{l}\text { Analyze whether discriminatory language } \\
\text { and verbal tone are reflected in the } \\
\text { dissemination of company information. }\end{array}$ & $\begin{array}{l}\text { They conclude that less compliant companies use } \\
\text { language and verbal tone to influence the message. } \\
\text { To hide their poor performance, these companies } \\
\text { use more optimistic language in environmental } \\
\text { reporting and seek to disguise the internal reasons } \\
\text { for their poor performance through complex and } \\
\text { dubious language. }\end{array}$ \\
\hline Simnett et al. (2009) & Empirical & $\begin{array}{l}\text { Analysis of sustainability reports and } \\
\text { factors associated with their preparation }\end{array}$ & $\begin{array}{l}\text { They explained that there is a strong link between } \\
\text { the production and dissemination of these reports } \\
\text { and the achievement of credibility, notably } \\
\text { through an external audit. }\end{array}$ \\
\hline
\end{tabular}




\subsection{Research Paradigms}

For the classification of research paradigms used in published studies, the taxonomy of Hopper and Powell (1985) was used, which points to the existence of three distinct research paradigms in management accounting research: the mainstream, the interpretative paradigm and the critical paradigm. To operationalize this classification, the criteria defined by several authors (Orlikowski and Baroudi 1991; Chen and Hirschheim 2004; Dwivedi and Kuljis 2008) were used, namely, whether the article resorted to primary data (empirical study or not); the nature of the empirical study developed (quantitative and qualitative), and the methods used.

Positivist research represents the most classical and predominant line of research orientation in management accounting (Modell et al. 2007). Its theoretical premises were built on neoclassical economic theory and organizational theory (Wickramasinghe and Alawattage 2007). This way of investigating views society objectively, views individual behavior as deterministic, the researcher here draws on positivist methodology to develop research (Chua 1986; Hopper and Powell 1985; Modell et al. 2007; Ryan et al. 2002) and favors quantitative data and generalization of findings (Ryan et al. 2002; Chua 1986). Therefore, researchers who adopt this type of research assume that management accounting functions independently and disconnected from human consciousness and organizational imperatives. For these researchers, management accounting practices are based on the requirement that there are linear relationships of cause and effect and that organizational practices are universal and independent of the surrounding context, i.e., they function similarly anywhere in the world (Simões and Rodrigues 2012). In this line of thought, the function of management accounting is to ensure that all organizational processes are executed according to plan and, thus, to ensure that resources are used effectively in dynamic and competitive contexts, argued Simões and Rodrigues (2012).

This means that positivist research emphasizes the relationships between things, which stems from the fact that positivism is not interested in the causes of phenomena, but rather how the relationships between facts are produced, studying them without interest in their practical consequences, i.e., the purpose of the researcher is to portray reality, not to judge it (Theóphilo and de Iudícibus 2001). On the other hand, in recent years, some interpretative research works have emerged, which, according to Silva and Silva (2013), attempts to understand the social nature of accounting practices. Its aim is not to generalize or predict future events based on present studies, but to understand daily events, social structures, the meanings that people attribute to it, including the behavior of individuals in a certain context. These ideas are shared by Ryan et al. (2002) who considered that this type of interpretation takes into account the relationship between daily actions and the dimensions of the overall structure, more specifically, in management accounting one seeks to understand how systems interact with their context; that is, researchers follow a holistic orientation.

As opposed to the positive paradigm, the interpretative perspective is based on the premise that social practices, which includes management accounting, are not a natural phenomenon, but a socially constructed phenomenon (Covaleski et al. 1996; Ryan et al. 2002), in which reality is understood as a result of a social construction process and the parties involved can change the social rules and practices that direct their behaviors (Simões and Rodrigues 2012). Additionally, Wickramasinghe and Alawattage (2007) argued that this perspective postulates that accounting practices are the result of the meanings and perceptions shared by the actors involved in the organizations. In other words, the interpretive perspective aims to understand and discover the meanings and beliefs underlying the actions of these actors, in which subjectivism is always implicit (Lourenço and Sauerbronn 2016).

In general, interpretive research uses qualitative methods, using an interactive process involving a field study, which is interpreted in its context from the perspective of the various actors. In this type of research, the researcher is not concerned with obtaining ultimate truths, but rather reports that reflect the various interpretations, since reality is considered to be a construction of its various participants (Silva and Silva 2013). 
Despite seeming, in the light of positivist theories, an inadmissible procedure, in interpretative research there is an involvement of the researcher himself in the object of investigation in which the interpretation obtained results much from his experience as a researcher (Silva and Silva 2013). The results of this type of research usually present an account of concrete situations, enabling various interpretations that are tested through case studies (Yin 2015).

Therefore, in epistemological and ontological terms, it can be seen that research in management accounting presents several theoretical approaches and research methods (Luft and Shields 2003). In historical terms, in research in this area, positivist research (more quantitative) has predominated over interpretative research (more qualitative) (Major 2008). In this context, it was found that there is a superiority of the empiricist philosophy, objective in the methodology adopted, mostly by researchers in the USA (Ryan et al. 2002). In Asia, the Pacific, and Europe, on the other hand, interpretative or alternative research has gained ground (Oliveira et al. 2009). This means that in Europe research in this area is accepted as multiparadigmatic, while Americans give preference to the positivist paradigm (Lukka 2010). However, the differences between the paradigms did not prevent a strong growth of publications on management accounting (Luft and Shields 2003). An example of this growth, in particular of qualitative research compared to quantitative research is the work of Parker (2012), who pointed out that the focus on qualitative research has been a contribution to the understanding and critique of management and accounting systems. This argument had already been corroborated by Lukka and Kasanen (1995) who concluded that in-depth case studies allow the complexity of the processes analyzed to be understood and provide a critical understanding of the phenomena of organizations.

As already mentioned, in the USA the positivist paradigm predominates, thus research in management accounting gave way to research in the area of financial accounting (Lukka 2010). This conclusion is clairvoyant in the analysis of the top five US accounting journals, whose published articles are predominantly in financial accounting and framed within the positivist research paradigm (Merchant 2010).

In short, the positivist research in management accounting aims to develop tools and techniques that provide the efficient and effective management of organizations and is in line with the contingency theory, the agency theory, the transaction costs theory, among others, while the interpretive research aims to describe, interpret and theorize what is observed in organizations (Baxter and Chua 2003). It is also noted that the case study method can be used in any of these types of research-positivist or interpretive-(Bloomberg and Volpe 2012).

Finally, there is the critical research which advocates that the objectives of organizations are a result of negotiations; that the units of analysis of the phenomena are social interactions and subordination; that reality is characterized by actions of power, domination, and resistance; that accounting is a process of domination (Wickramasinghe and Alawattage 2007). Finally, this paradigm contributes to management accounting with the creation of a subjective language (Wickramasinghe and Alawattage 2007), which allows the highlighting of issues of social nature in the use of tools and techniques of that accounting (Baxter and Chua 2003).

In the clusters identified, and according to the terminology of Hopper and Powell (1985), it can be concluded that in cluster 1 research work using a more interpretative approach (e.g., Gray et al. 1995) arises, given the ontological positioning of researchers and the theoretical and methodological approaches used (qualitative research work). On the other hand, in clusters 2 and 3, the traditional positive research stream predominates (e.g., Cho and Patten 2007; Cho et al. 2015), with essentially quantitative work. It should also be noted that the Accounting, Auditing and Accountability Journal and Accounting, Organization and Society publish articles on this topic which fit into the three research paradigms. This plurality in terms of the research paradigms of the articles is related to the fact that in the United Kingdom there is a tendency to accept papers that follow approaches other than the traditional one (positive approach) and even some criticism of the predominant 
positivism in the US (Lukka 2010; Merchant 2010). Some authors even argue that this change in epistemological and ontological assumptions has been visible in recent years in management accounting research (e.g., Ryan et al. 2002), and has not prevented increased research in this area (Luft and Shields 2003).

In short, it can be seen that any of the three research paradigms identified by Hopper and Powell (1985) can be used in social accounting research without calling into question the robustness and quality of the studies undertaken, be they theoretical or practical. On the other hand, this plurality shows the variety in the epistemological, ontological, and methodological assumptions of researchers and studies. The interpretative paradigm involves greater subjectivity, since when it comes to responding to the how and why, the researcher's involvement is unquestionable; however, this condition does not call into question the validity, reliability, quality and contribution of such research to the evolution of scientific knowledge.

\section{Concluding Remarks}

In the study developed, bibliometric techniques helped us map the literature and understand the evolution of research on the dissemination of information on social accounting. This research work allows us to conclude that social accounting is an attractive research area since the year 1970 due to the discussion about sustainable development issues and research contributions to sustainability, with effects in the present and the future.

To provide answers to the objectives initially defined, it is concluded that at the level of social accounting great emphasis has been given to its dissemination, which is evidenced by the results obtained in cluster 2 of the published articles. Cluster 1, on the other hand, makes it possible to argue that the theory of legitimacy is one of the most widely used frameworks in studies on social accounting.

However, Cluster 3, in association with Cluster 1, reveals that dissemination is still a controversial issue in information content. Thus, it can be seen that social accounting still has some limitations in its implementation and interconnection with "traditional" accounting. On the other hand, being its disclosure understood as a voluntary practice for companies/economic groups to obtain/maintain their external and internal legitimacy before all interested parties, there is still some heterogeneity in the information disclosed.

Considering that the search for institutional legitimacy is directly related to institutional theory, the latter is appropriate for work that focuses on a specific company's structure or the adoption of information dissemination practices by similar organizations (mimetic isomorphism). Thus, it can be seen that in work in this area. At the same time, legitimacy theory and institutional theory are used to study specific organizations, and stakeholder theory allows the analysis of interactions between groups of stakeholders or between organizations.

There are, however, pressures for actors in the international context to implement accounting practices that are socially and ethically responsible, in addition to accounting practices that can only be considered in the environmental approach. These practices should be embedded in traditional accounting systems and information should be disclosed in social reports to promote transparency, credibility and enable sustainable performance, thus demonstrating a proactive attitude in this area.

In parallel with the analysis of these theoretical implications, a descriptive mapping of the literature on this subject (figures, charts, and tables) was carried out, systematizing the information and helping future research on the subject, with an indication of the topics that have most aroused the interest of the academic world.

In addition to this, a summary of the paradigmatic plurality revealed by research in social accounting in recent years has been presented. It is noted that positivist research is no longer predominant, giving way to interpretative research and critical research. Mathews (1997) argues that the traditional paradigm no longer meets the needs of research, and many of the studies undertaken no longer fit the assumptions of the traditional model. In interpretative research, the researcher seeks to study a social phenomenon in a particular 
context and may become involved in the phenomenon, and tries to interpret the results in the light of the theories that support it. In critical research, the researcher seeks to understand the social world better and promote the necessary social change. He or she seeks to emancipate the individual, freeing him or her from excessively influential discourses that may restrict his or her ability to reflect (Gendron 2018). For example, Kamla et al. (2012) studied the social accounting perceptions of Syrian accounting professionals and concluded that the sociopolitical and socio-economic context had slowed social accounting development in Syria. This means that, like traditional accounting, social accounting research has shifted from theoretical questions, processes, and norms to focus on social phenomena.

In short, in addition to the mapping of literature in elite journals, another theoretical contribution was the identification of the paradigms and research approaches underlying this theme. Thus, it was concluded that social accounting is a multifaceted area that allows research methodologies, and the paradigms used, to be varied and, as such, allow for a greater theoretical and practical deepening of the analyzed themes. Some critical research, associated with social and environmental responsibility, stands out here on which there is still a strong debate. This means that the study of social accounting can also be approached critically, when trying to respond to the challenges of sustainability imposed by climate change or, carbon emissions, among many other aspects.

It is also important to note some academic and management implications. Academically, this study suggests that this theme is still emerging and current since the dissemination of social accounting still needs to be improved, namely, the inclusion of more information on actions in the local community and the implementation of measures that minimize the negative impacts of some of the strategies followed. Further, the motivation for disclosure should not be used as a tool to entice stakeholders for the sake of convenience, but because they actually want to be socially responsible. This means, in management terms, that this disclosure should not be driven by mere compliance with the law, on the contrary, it should be with a view to generating internal and external added value. A further implication for theory and practice is that it has been shown that in any type of research on in social accounting research, any of the research paradigms can be used without jeopardizing the robustness and quality of the studies carried out, whether theoretical or practical. On the other hand, this plurality shows the variety in the epistemological, ontological and methodological assumptions of researchers and studies. The interpretive paradigm involves greater subjectivity, because when the intention is to answer the how and why, the researcher's involvement is unquestionable; however, this does not jeopardize the validity, reliability, quality, and contribution of these studies to the development of scientific knowledge.

Like any research work, this study has some limitations, notably, because it has been limited to the Web of Science database. However, this is one of the most widely recognized in the scientific and academic community. Regarding this limitation, it should be added that the same research was carried out in the Scopus database, and it was found that articles not common to both databases did not influence the final result significantly. Similarly, the analysis of paradigms confined only to articles included in clusters represents a limitation.

Finally, and as topics for future research, it is suggested to study the regulations on the type of information to be included in disseminating social reports and its standardization concerning the Global Reporting Index (GRI) standards. It would also be important to search in other relevant academic databases for articles related to the topic under analysis and add them to the final base to be analyzed in Rstudio, and thus enrich the knowledge of this topic, which suggests another future track. Furthermore, broadening the search terms used in this study is another future clue, since the topic of social accounting can be developed at various levels, for instance to include "sustainability reports", "non-financial information", and other similar ones. 
Author Contributions: Conceptualization, M.R., M.d.C.A., and R.S.; methodology, M.R. and R.S.; software, R.S.; validation, M.R. and M.d.C.A.; formal analysis, M.R. and C.O.; investigation, M.R., M.d.C.A., J.V., V.V., C.O., and R.S.; writing—original draft preparation, M.R., M.d.C.A., J.V., C.O., and R.S.; writing-review and editing, M.R., M.d.C.A., J.V., V.V., C.O., and R.S.; visualization, M.R.; supervision, M.d.C.A.; project administration, M.R., M.d.C.A., and R.S.; funding acquisition, M.R., R.S., C.O., V.V., and J.V. All authors have read and agreed to the published version of the manuscript.

Funding: The work of the author Rui Silva is supported by national funds, through the FCTPortuguese Foundation for Science and Technology under the project UIDB/04011/2020. The work of the author Cidália Oliveira is financed by NIPE (Center for Research in Economics and Management), University of Minho, Braga, Portugal.

Acknowledgments: The authors gratefully acknowledge University of Trás-os-Montes and Alto Douro and CETRAD (Center for Transdisciplinary Development Studies) and NIPE (Center for Research in Economics and Management), University of Minho, Braga, Portugal.

Conflicts of Interest: The authors declare no conflict of interest.

\section{References}

Adams, Carol A. 2002. Internal organisational factors influencing corporate social and ethical reporting. Accounting, Auditing $\mathcal{E}$ Accountability Journal 15: 223-50.

Adams, Carol A. 2004. The ethical, social and environmental reporting-performance portrayal gap. Accounting, Auditing E Accountability Journal 17: 731-57.

Adedeji, Babatunji Samuel, Tze Sen Ong, Amer Hamzah Jantan, and Mohammad Mizanur Rahman. 2018. National Culture and Corporate Governance: A Conceptual Review. In Perspectives in Organizational Behaviour. Edited by Amer Hamzah Jantan. Serdang: Universiti Putra Malaysia Press.

Anstätt, Kerstin, and Jürgen Volkert. 2016. Corporate Social Responsibility impacts on sustainable human development. Ekonomski vjesnik/Econviews-Review of Contemporary Business, Entrepreneurship and Economic Issues 29: 193-210.

Aria, Massimo, and Corrado Cuccurullo. 2017. bibliometrix: An R-tool for comprehensive science mapping analysis. Journal of Informetric 11: 959-75. [CrossRef]

Bandara, Wasana, Suraya Miskon, and Erwin Fielt. 2011. A systematic, tool-supported method for conducting literature reviews in information systems. Paper presented at ECIS 2011 Proceedings [19th European Conference on Information Systems], Helsinki, Finland, June 9-11; Atlanta: AIS Electronic Library (AISeL)/Association for Information Systems, pp. 1-13.

Bansal, Pratima. 2005. Evolving sustainably: A longitudinal study of corporate sustainable development. Strategic Management Journal 26: 197-218.ss. [CrossRef]

Baxter, Jane, and Wai Fong Chua. 2003. Alternative management accounting research-Whence and whither. Accounting, Organizations and Society 28: 97-126. [CrossRef]

Bebbington, Jan, and Rob Gray. 2001. An Account of Sustainability: Failure, Success and a Reconceptualization. Critical Perspectives on Accounting 12: 557-87. [CrossRef]

Bebbington, Jan, and Carlos Larrinaga-González. 2014. Accounting and sustainable development: An exploration. Accounting, Organizations and Society 39: 395-413. [CrossRef]

Bebbington, Jan, and Jeffrey Unermen. 2018. Achieving the United Nations sustainable development goals. Accounting, Auditing $\mathcal{E}$ Accountability Journal 31: 2-24.

Bebbington, Jan, Judy Brown, Bob Frame, and Ian Thomson. 2007. Theorizing engagement: The potential of a critical dialogic approach. Accounting, Auditing \& Accountability Journal 20: 356-81.

Bebbington, Jan, Elizabeth A. Kirk, and Carlos Larrinaga. 2012. The production of normativity: A comparison of reporting regimes in Spain and the UK. Accounting, Organizations and Society 37: 78-94. [CrossRef]

Becker, Saul, Alan Bryman, and Harry Ferguson, eds. 2012. Understanding Research for Social Policy and Social Work 2E: Themes, Methods and Approaches. Bristol: Policy Press.

Bloomberg, Linda Dale, and Marie Volpe. 2012. Chapter 1 Introduction to Your Study. In Completing Your Qualitative Dissertation: A Roadmap from Beginning to End. Thousand Oaks: SAGE Publications, pp. 233-36. [CrossRef]

Brown, Judy, and Michael Fraser. 2006. Approaches and perspectives in social and environmental accounting: An overview of the conceptual landscape. Business Strategy and the Environment 15: 103-17. [CrossRef]

Buhr, Nola, and Sara Reiter. 2006. Ideology, the Environment and One World View: A Discourse Analysis of Noranda's Environmental and Sustainable Development Reports. Advances in Environmental Accounting and Management 3: 1-48. [CrossRef]

Chen, WenShin, and Rudy Hirschheim. 2004. A paradigmatic and methodological examination of information systems research from 1991 to 2001. Information Systems Journal 14: 197-235. [CrossRef]

Cho, Charles H., and Dennis M. Patten. 2007. The role of environmental disclosures as tools of legitimacy: A research note. Accounting, Organizations and Society 32: 639-47. [CrossRef] 
Cho, Charles H., Robin W. Roberts, and Dennis M. Patten. 2010. The Language of US Corporate Environmental Disclosure. Accounting Organizations \& Society 35: 431-43.

Cho, Charles H., Giovanna Michelon, Dennis M. Patten, and Robin W. Roberts. 2015. CSR disclosure: The more things change ... ? Accounting, Auditing E Accountability Journal 28: 14-35.

Chua, Wai Fong. 1986. Radical Developments in Accounting Thought. The Accounting Review 4: 601-32.

Cooper, David J., and Michael J. Sherer. 1984. The value of corporate accounting reports: Arguments for a political economy of accounting. Accounting, Organizations and Society 9: 207-32. [CrossRef]

Cooper, Christine, Phil Taylor, Newman Smith, and Lesley Catchpowle. 2005. A discussion of the political potential of social accounting. Critical Perspectives on Accounting 16: 951-74. [CrossRef]

Covaleski, Mark A., Mark W. Dirsmith, and Sajay Samuel. 1996. Managerial Accounting Research: The Contributions of Organizational and Sociological Theories. Journal of Management Accounting Research 8: 1-36. Available online: http:/ / ezproxy.library.capella.edu/ login?url=http:/ / search.ebscohost.com/login.aspx?direct=true\&db=bth\&AN=9702114350\&site=ehost-live\&scope=site (accessed on 10 December 2020).

Dahlsrud, Alexander. 2008. How Corporate Social Responsibility is Defined: An Analysis of 37 Definitions. Corporate Social Responsibility and Environmental Management 15: 1-13. [CrossRef]

de Lima Voss, Barbara, David Bernard Carter, and Bruno Meirelles Salotti. 2017. Hegemonies, politics and the Brazilian academy in social and environmental accounting: A post-structural note. Advances in Environmental Accounting E Management 6: 13-68.

Deegan, Craig. 2002. Introduction: The legitimising effect of social and environmental disclosures-A theoretical foundation. Accounting, Auditing \& Accountability Journal 15: 282-311. [CrossRef]

Deegan, Craig. 2014. An overview of legitimacy theory as applied within the social and environmental accounting literature. Sustainability Accounting and Accountability 2: 248-72.

Deegan, Craig Michael. 2019. Legitimacy theory. Accounting, Auditing E Accountability Journal 32: 2307-29.

Deegan, Craig, and Christopher Blomquist. 2006. Stakeholder influence on corporate reporting: An exploration of the interaction between WWF-Australia and the Australian minerals industry. Accounting, Organizations and Society 31: 343-72. [CrossRef]

Derviş, Hamid. 2019. Bibliometric analysis using Bibliometrix an R Package. Journal of Scientometric Research 8: 156-60.

Dhaliwal, Dan S., Oliver Zhen Li, Albert Tsang, and Yong George Yang. 2011. Voluntary nonfinancial disclosure and the cost of equity capital: The initiation of corporate social responsibility reporting. Accounting Review 86: 59-100. [CrossRef]

Dhaliwal, Dan S., Suresh Radhakrishnan, Albert Tsang, and Yong George Yang. 2012. Nonfinancial disclosure and analyst forecast accuracy: International evidence on corporate social responsibility disclosure. Accounting Review 87: 723-59. [CrossRef]

DiMaggio, Paul J., and Walter W. Powell. 1983. The iron cage revisited: Institutional isomorphism and collective rationality in organizational fields. American Sociological Review 48: 147-60. [CrossRef]

Dowling, John, and Jeffrey Pfeffer. 1975. Organizational Legitimacy: Social Values and Organizational Behavior. The Pacific Sociological Review 18: 122-36. [CrossRef]

Dwivedi, Yogesh K., and Jasna Kuljis. 2008. Profile of IS research published in the European Journal of Information Systems. European Journal of Information Systems 17: 678-93. [CrossRef]

Ekundayo, Temitope Cyrus, and Anthony I. Okoh. 2018. A global bibliometric analysis of Plesiomonas-related research (1990-2017). PLoS ONE 13: e0207655. [CrossRef]

Erkens, Michael, Luc Paugam, and Hervé Stolowy. 2015. Non-financial information: State of the art and research perspectives based on a bibliometric study. Comptabilité-Contrôle-Audit 21: 15. [CrossRef]

Freeman, R. Edward. 1984. Strategic Management: A Stakeholder Approach Marshall. New York: Harpercollins College Div.

Gendron, Yves. 2018. On the elusive nature of critical (accounting) research. Critical Perspectives on Accounting 50: 1-12. [CrossRef]

Grácio, Maria Cláudia Cabrini. 2016. Acoplamento bibliográfico e análise de cocitação: Revisão teórico-conceitual. Encontros Bibli: Revista eletrônica de biblioteconomia e ciência da informação 21: 82-99.

Gray, Rob. 1992. Accounting and environmentalism: An exploration of the challenge of gently accounting for accountability, transparency and sustainability. Accounting, Organizations and Society 17: 399-425. [CrossRef]

Gray, Anne. 2002. Jobseekers and gatekeepers: The rote of the private employment agency in the placement of the unemployed. Work, Employment and Society 16. [CrossRef]

Gray, Rob. 2010. Is accounting for sustainability actually accounting for sustainability ... and how would we know? An exploration of narratives of organisations and the planet. Accounting, Organizations and Society 35: 47-62. [CrossRef]

Gray, Rob, Reza Kouhy, and Simon Lavers. 1995. Corporate social and environmental reporting: A review of the literature and a longitudinal study of UK disclosure. Accounting, Auditing \& Accountability Journal 8: 47-77. [CrossRef]

Gray, Rob, Dave Owen, and Carol Adams. 1996. Accounting \& Accountability: Changes and Challenges in Corporate Social and Environmental Reporting. Upper Saddle River: Prentice Hall.

Gray, Rob, Colin Dey, Dave Owen, Richard Evans, and Simon Zadek. 1997. Struggling with the praxis of social accounting: Stakeholders, accountability, audits and procedures. Accounting, Auditing \& Accountability Journal 10. [CrossRef]

Gray, Rob, Jesse Dillard, and Crawford Spence. 2009. Social accounting research as if the world matters: An essay in Postalgia and a new absurdism. Public Management Review 11: 545-73. [CrossRef]

Herbohn, Kathleen. 2005. A full cost environmental accounting experiment. Organizations and Society 30: 519-36. [CrossRef]

Higgins, Colin, and Carlos Larrinaga. 2014. 16 Sustainability reporting. Sustainability Accounting and Accountability 1: 273. 
Hines, Ruth D. 1991. The FASB's conceptual framework, financial accounting and the maintenance of the social world. Accounting, Organizations and Society 16: 313-31. [CrossRef]

Hirshleifer, Jack. 1971. The Private and Social Value of Information and the Reward to Inventive Activity. American Economic Review 61: 561-74. [CrossRef]

Hopper, Trevor, and Andrew Powell. 1985. Making Sense of Research into The Organizational and Social Aspects of Management Accounting: A Review of Its Underlying Assumptions. Journal of Management Studies 22: 429-65. [CrossRef]

Huang, Cheng-Li, and Fan-Hua Kung. 2010. Drivers of Environmental Disclosure and Stakeholder Expectation: Evidence from Taiwan. Journal of Business Ethics 96: 435-51. [CrossRef]

Jalal, Samir Kumar. 2019. Co-authorship and co-occurrences analysis using Bibliometrix R-package: A casestudy of India and Bangladesh. Annals of Library and Information Studies (ALIS) 66: 57-64.

Jennifer Ho, Li-Chin, and Martin E. Taylor. 2007. An empirical analysis of triple bottom line reporting and its determinants: Evidence from the United States and Japan. Journal of International Financial Management E Accounting 18: 123-50.

Jones, Michael John. 2003. Accounting for biodiversity: Operationalising environmental accounting. Accounting, Auditing $\mathcal{E}$ Accountability Journal 16: 762-89.

Kamla, Rania, Sonja Gallhofer, and Jim Haslam. 2012. Understanding Syrian accountants' perceptions of, and attitudes towards, social accounting. Accounting, Auditing \& Accountability Journal 25: 1170-205.

Khan, Ismail, Imran Khan, and Bilal bin Saeed. 2019. Does board diversity affect quality of corporate social responsibility disclosure? Evidence from Pakistan. Corporate Social Responsibility and Environmental Management 26: 1371-81. [CrossRef]

Krippendorff, Klaus. 1980. Validity in Content Analysis. Computerstrategien Für Die Kommunikationsanalyse, 69-112. Available online: http:/ / repository.upenn.edu/asc_papers/291 (accessed on 20 January 2021).

Krippendorff, Klaus. 2004. Reliability in Content Analysis. Human Communication Research 30: 411-33. [CrossRef]

Krippendorff, Klaus. 2012. Content Analysis: An Introduction to Its Methodology. Thousand Oaks: Sage Publications.

Kulevicz, Rosane Aparecida, Grasiela Edith de Oliveira Porfirio, Ozeni Souza de Oliveira, Arturo Alejandro Zavala Zavala, Benedito Albuquerque da Silva, and Michel Constantino. 2020. Influence of sustainability reports on social and environmental issues: Bibliometric analysis and the word cloud approach. Environmental Reviews 28: 380-86. [CrossRef]

Larrinaga, Carlos, Francisco Carrasco, Carmen Correa, Fernando Llena, and José Moneva. 2002. Accountability and accounting regulation: The case of the Spanish environmental disclosure standard. European Accounting Review 11: 723-40. [CrossRef]

Larrinaga-González, Carlos, and Jan Bebbington. 2001. Accounting change or institutional appropriation?-A case study of the implementation of environmental accounting. Critical Perspectives on Accounting 12: 269-92.

Larrinaga-González, Carlos, Francisco Carrasco-Fenech, Francisco Javier Caro-González, Carmen Correa-Ruíz, and José María PáezSandubete. 2001. The role of environmental accounting in organizational change-An exploration of Spanish companies. Accounting, Auditing \& Accountability Journal 14: 213-39.

Liu, Xianbing, and Venkatachalam Anbumozhi. 2009. Determinant factors of corporate environmental information disclosure: An empirical study of Chinese listed companies. Journal of Cleaner Production 17: 593-600. [CrossRef]

Lourenço, Rosenery Loureiro, and Fernanda Filgueiras Sauerbronn. 2016. Revistando possibilidades epistemológicas em contabilidade gerencial: Em busca de contribuições de abordagens interpretativas e críticas no Brasil. Revista Contemporánea de Contabilidade 55: 99-122. [CrossRef]

Lu, Yingjun, and Indra Abeysekera. 2014. Stakeholders' power, corporate characteristics, and social and environmental disclosure: Evidence from China. Journal of Cleaner Production 64: 426-36. [CrossRef]

Luft, Joan, and Michael D. Shields. 2003. Mapping management accounting: Graphics and guidelines for theory consistent empirical research. Accounting, Organizations and Society 28: 1-3. [CrossRef]

Lukka, Kari. 2010. The roles and effects of paradigms in accounting research. Management Accounting Research 21: 110-15. [CrossRef]

Lukka, Kari, and Eero Kasanen. 1995. The problem of generalizability: Anecdotes and evidence in accounting research. Accounting, Auditing \& Accountability Journal 8: 71-90.

Major, Maria João. 2008. Reflexão sobre a investigação em Contabilidade de Gestão. Revista Portuguesa e Brasileira de Gestão 7: 43-50.

Mathews, M. Reg. 1997. Twenty-five years of social and environmental accounting research. Accounting, Auditing and Accountability Journal 10: 481-531. [CrossRef]

Matuszak, Łukasz, and Ewa Różańska. 2017. CSR disclosure in Polish-listed companies in the light of Directive 2014/95/EU requirements: Empirical evidence. Sustainability 9: 2304. [CrossRef]

Mentzer, John T., and Kenneth B. Kahn. 1995. A framework of logistics research. Journal of Business Logistics 16: 231.

Merchant, Kenneth A. 2010. Paradigms in accounting research: A view from North America. Management Accounting Research 21: 116-20. [CrossRef]

Merigó, José M., and Jian-Bo Yang. 2017. Accounting Research: A Bibliometric Analysis. Australian Accounting Review 27: 71-100. [CrossRef]

Modell, Sven, Kerry Jacobs, and Fredrika Wiesel. 2007. A process (re)turn?: Path dependencies, institutions and performance management in Swedish central government. Management Accounting Research 18: 453-75. [CrossRef]

Moser, Donald V., and Patrick R. Martin. 2012. A broader perspective on corporate social responsibility research in accounting. Accounting Review 87: 797-806. [CrossRef] 
Murray, Alan, Donald Sinclair, David Power, and Rob Gray. 2006. Do financial markets care about social and environmental disclosure? Further evidence and exploration from the UK. Accounting, Auditing E Accountability Journal 19: 228-55.

Neu, Dean, Hussein Warsame, and Kathryn Pedwell. 1998. Managing public impressions: Environmental disclosures in annual reports. Accounting, Organizations and Society 23: 265-82. [CrossRef]

Niyama, Jorge Katsumi, and Cat Silva. 2014. Teoria Avançada da Contabilidade. Atlas: São Paulo.

O'Dwyer, Brendan. 2005. The construction of a social account: A case study in an overseas aid agency. Accounting, Organizations and Society 30: 279-96.

Oliveira, João, Samuel Pereira, and João Ribeiro. 2009. Investigação em Contabilidade de Gestão. Contabilidade e Controlo de Gestão 1: $1-20$.

Orlikowski, Wanda J., and Jack J. Baroudi. 1991. Studying information technology in organizations: Research approaches and assumptions. Information Systems Research 2: 1-28. [CrossRef]

Orlitzky, Marc, Frank L. Schmidt, and Sara L. Rynes. 2003. Corporate social and financial performance: A meta-analysis. Organization Studies 24. [CrossRef]

Parker, Lee D. 2012. Qualitative management accounting research: Assessing deliverables and relevance. Critical Perspectives on Accounting 23: 54-70. [CrossRef]

Patten, Dennis M. 1992. Intra-industry environmental disclosures in response to the Alaskan oil spill: A note on legitimacy theory. Accounting, Organizations and Society 17: 471-75. [CrossRef]

Patten, Dennis M. 2005. The accuracy of financial report projections of future environmental capital expenditures: A research note. Accounting, Organizations and Society 30: 457-68. [CrossRef]

Patten, Dennis M., and Hyemi Shin. 2019. Sustainability Accounting, Management and Policy Journal's contributions to corporate social responsibility disclosure research: A review and assessment. Sustainability Accounting, Management and Policy Journal 10: 26-40. [CrossRef]

Prasad, Sameer, and Jasmine Tata. 2005. Publication patterns concerning the role of teams/groups in the information systems literature from 1990 to 1999. Information \& Management 42: 1137-48.

Quesado, Patricia, and Rui Silva. 2021. Activity-Based Costing (ABC) and Its Implication for Open Innovation. Journal of Open Innovation: Technology, Market, and Complexity 7: 41. [CrossRef]

Ramanathan, Kavasseri V. 1976. Toward a Theory of Corporate Social Accounting toward A Theory of Corporate Social Accounting. The Accounting Review 51: 516-28.

Reverte, Carmelo. 2009. Determinants of corporate social responsibility disclosure ratings by Spanish listed firms. Journal of Business Ethics 88: 351-66. [CrossRef]

Riahi-Belkaoui, Ahmed. 2004. Accounting Theory, 5th ed. London: Thomson.

Roberts, Robin W. 1992. Determinants of corporate social responsibility disclosure: An application of stakeholder theory. Accounting, Organizations and Society 17: 595-612. [CrossRef]

Rodrigues, Margarida, and Luis Mendes. 2018. Mapping of the literature on social responsibility in the mining industry: A systematic literature review. Journal of Cleaner Production 181. [CrossRef]

Rowley, Jennifer, and Frances Slack. 2004. Conducting a literature review. Management Research News 27: 31-39. [CrossRef]

Rubenstein, Daniel Blake. 1992. Bridging the gap between green accounting and black ink. Accounting, Organizations and Society 17: 501-8. [CrossRef]

Ryan, Bob, Robert W. Scapens, and Michael Theobald. 2002. Research Method and Methodology in Finance and Accounting. London: Thomson.

Seuring, Stefan, and Stefan Gold. 2012. Conducting content-analysis based literature reviews in supply chain management. Supply Chain Management 17: 544-55. [CrossRef]

Seuring, Stefan, and Martin Müller. 2008. From a literature review to a conceptual framework for sustainable supply chain management. Journal of Cleaner Production 16: 1699-710. [CrossRef]

Sikacz, Hanna. 2017. Csr Reporting As an Object of Bibliometric Analysis of Scientific Publications. Prace Naukowe Uniwersytetu Ekonomicznego We Wroctawiu, 160-69. [CrossRef]

Sikka, Prem. 2010. Smoke and mirrors: Corporate social responsibility and tax avoidance. Accounting Forum 34: 3-4. [CrossRef]

Silva, Rui, and Paulino Silva. 2013. O contributo dos métodos qualitativos na investigação em contabilidade de gestão. Indagatio Didactica 5: 1047-63.

Simnett, Roger, Ann Vanstraelen, and Wai Fong Chua. 2009. Assurance on Sustainability Reports: An International Comparison An International Comparison. The Accounting Review 84: 937-67. [CrossRef]

Simões, Ana Maria Dias, and José Azevedo Rodrigues. 2012. A abordagem da velha economia institucional na investigação em contabilidade e controlo de gestão contributos teóricos. Revista Iberoamericana de Contabilidad de Gestión 10: 1-24.

Skouloudis, Antonis, Konstantinos Evangelinos, and Fotis Kourmousis. 2010. Assessing non-financial reports according to the Global Reporting Initiative guidelines: Evidence from Greece. Journal of Cleaner Production 18: 426-38. [CrossRef]

Skouloudis, Antonis, Nikoleta Jones, Chrisovaladis Malesios, and Konstantinos Evangelinos. 2014. Trends and determinants of corporate non-financial disclosure in Greece. Journal of Cleaner Production 68: 174-88. [CrossRef]

Soana, Maria-Gaia. 2011. The relationship between corporate social performance and corporate financial performance in the banking sector. Journal of Business Ethics 104: 133-48. [CrossRef] 
Spens, Karen M., and Gyöngyi Kovács. 2006. A content analysis of research approaches in logistics research. International Journal of Physical Distribution \& Logistics Management 36: 374-90.

Suchman, Mark C. 1995. Managing Legitimacy: Strategic and Institutional Approaches. Academy of Management Review 20: 571-610. [CrossRef]

Theóphilo, Carlos Renato, and Sérgio de Iudícibus. 2001. As novas abordagens metodológicas na pesquisa em contabilidade gerencial. In Cruzando fronteras: Tendencias de contabilidad directiva para el siglo XXI: Actas VII Congreso Internacional de Costos y II Congreso de la Asociación Española de Contabilidad Directiva. Pamplona: Servicio de Publicaciones, p. 197.

Tranfield, David, David Denyer, and Palminder Smart. 2003. Towards a methodology for developing evidence-informed management knowledge by means of systematic review. British journal of management 14: 207-22. [CrossRef]

Treinta, Fernanda Tavares, José Rodrigues Farias Filho, Annibal Parracho Sant'Anna, and Lúcia Mathias Rabelo. 2014. Metodologia de pesquisa bibliográfica com a utilização de método multicritério de apoio à decisão. Production 24: 508-20. [CrossRef]

Tschopp, Daniel, and Ronald J. Huefner. 2015. Comparing the Evolution of CSR Reporting to that of Financial Reporting. Journal of Business Ethics 127: 565-77. [CrossRef]

UN. 2015. Transforming Our World: The 2030 Agenda for Sustainable Development. Available online: https:/ / sustainabledevelopment.un. org/content/documents /21252030\%20Agenda\%20for\%20Sustainable\%20Development\%20web.pdf (accessed on 10 December 2020).

UN. 2016. The Sustainable Development Goals Report 2019. Available online: https://unstats.un.org/sdgs/report/2019/TheSustainable-Development-Goals-Report-2019.pdf (accessed on 10 December 2020).

UNWCED. 1987. Our Common Future (The Brundtland Report). Oxford: Oxford University Press. Available online: https:// sustainabledevelopment.un.org/content/documents/5987our-common-future.pdf (accessed on 10 December 2020).

Van de Burgwal, Dion, and Rui José Oliveira Vieira. 2014. Environmental disclosure determinants in Dutch listed companies. Revista Contabilidade E Finanças 25: 60-78.

Verrecchia, Robert E. 1983. Discretionary disclosure. Journal of Accounting and Economics 5: 179-94. [CrossRef]

Waddock, Sandra A., and Samuel B. Graves. 1997. The corporate social performance-financial performance link. Strategic Management Journal 18: 303-19. [CrossRef]

Wickramasinghe, Danture, and Chandana Alawattage. 2007. Management Accounting Change: Approaches and Perspectives. London: Routledge.

Wiseman, Joanne. 1982. An evaluation of environmental disclosures made in corporate annual reports. Accounting, Organizations and Society 7: 53-63. [CrossRef]

Yin, Robert K. 2015. Case Study Research: Design and Methods-Applied Social Research Methods Series, 6th ed. Thousand Oaks: Sage Publications, Inc. 